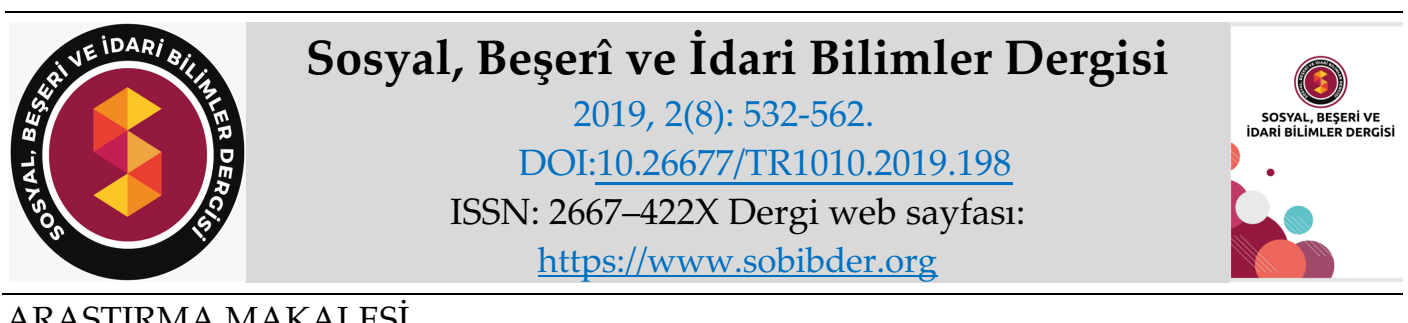

ARAŞTIRMA MAKALESI

\title{
Avrupa Müzelerinde Kullanılan Güncel Sergileme Teknolojileri Üzerine Bir Araştırma ${ }^{1}$
}

Doçent Burak BOYRAZ, Yıldız Teknik Üniversitesi, Sanat ve Tasarım Fakültesi, Sanat Bölümü, İstanbul, e-posta: bboyraz@yildiz.edu.tr ORCID: https://orcid.org/0000-0002-1373-7234

Öz

Müzecilik disiplini diğer bilim dallarından faydalanarak ivmelenen ve teknolojiden azami düzeyde yararlanmaya gayret gösteren bir bilim dalıdır. Bu disiplinin temel işlevlerinden biri olan "sergileme" ise genç kuşakların talep ve beklentilerini yerine getirebilecek türde bir yenilenme kabiliyetine sahiptir. Araştırma dâhilinde sergileme işlevi; bilgi toplumlarının ihtiyaçlarını karşılamak için edindiği yeni araçlar ekseninde ele alınmıştır. İncelenen temel konu Avrupa müzelerinde geride bıraktığımız beş yıllık zaman diliminde (2012 ve 2017 yılları arasında) kullanılan "sergileme teknolojileridir". Konu dâhilinde topraklarının tamamı ya da bir kısmı söz konusu kıtada bulunan ülkelerin müzelerinde yapılan saha araştırmaları ile sergileme teknolojilerinin ulaştığı noktayı tartışmak, ilgili araçların bilgi toplumlarına sunduğu güncel olanakları irdelemek ve sergileme yöntemleri çerçevesinde Türkiye müzelerinin referans alabileceği yakın dönemli sergileri / müzeleri tespit etmek amaçlanmıştır. Bu doğrultuda metnin ilk bölümünde müze sergilerinin 1980 sonrasındaki dönüşümünden bahsedilmiştir. Bilgi toplumlarının niteliklerine ve son dönemlerin popüler kuşak gruplamalarından birine de $(X, Y$ ve $Z$ kuşakları) temas eden bu bölümü takiben saha araştırmalarında gözlem metodu ile edinilen veriler sunulmuştur. Veriler eşliğinde Avrupa müzelerinin 2012 ve 2017 arasındaki sergilemelerine dair birinci elden görseller takdim edilmiş ardından genel bir değerlendirme yapılmıştır. Sonuç başlığı altında yapılan genel değerlendirmede toplanan veriler üzerinden araştırmanın amaçları ile ilgili tespitlere ve çıkarımlara yer verilmiştir.

Anahtar Kelimeler: Müzecilik, Müze Yönetimi, Sergi, Sergileme, Sergileme Teknolojileri.

Makale Gönderme Tarihi: 11.06 .2019

Makale Kabul Tarihi: 26.08.2019

\section{Önerilen Atıf:}

Boyraz, B. (2019). Avrupa Müzelerinde Kullanılan Güncel Sergileme Teknolojileri Üzerine Bir Araştırma, Sosyal, Beşeri ve İdari Bilimler Dergisi, 2(8): 532-562.

(c) 2019 Sosyal, Beşerî ve İdari Bilimler Dergisi.

\footnotetext{
${ }^{1}$ Araştırma beş yıllık süreçte dâhil olunan Avrupa Birliği / üniversite destekli projelere, yurt dışı görevlendirmelerine ve anahtar kelimeleri restorasyon ve konservasyon olan lisansüstü tez araştırmasına paralel biçimde gerçekleştirilmiştir. Metin; "müze uzmanlarına, küratör ve sanat yönetmenlerine" görsel ağırlıklı güncel bir kaynak sunmak hedefiyle bu araştırmaların bir yan çıktısı olarak kaleme alınmıştır.
} 


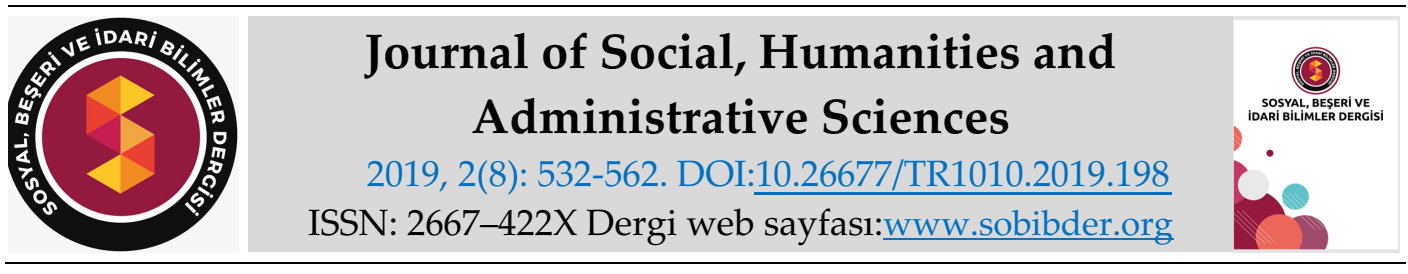

RESEARCH PAPER

A Study on Actual Exposition Technologies Used in European Museums

Associate Prof. Burak BOYRAZ, Yıldız Teknik University, Faculty of Art and Design, Department of Art, İstanbul, e-mail: bboyraz@yildiz.edu.tr ORCID: https://orcid.org/0000-0002-1373-7234

\begin{abstract}
The museology is a science that accelerates using other disciplines, trying to achieve maximum utilization of the technology. And as one of the basic functions of this discipline, "exposition" has an ability of renewal that could fulfill the demands and expectations of young generations. In this study, the exposition function has been dealt with in connection with those new instruments acquired by the information societies to meet their needs. This study principally examines the "exposition technologies" used in the European museums in the past five years period (between 2012 and 2017). The study aims to discuss the current achievement of exposition technologies in the West by using the field research carried out in the museums of those countries whose territory remains within the continent in part or in whole and further attempts to emphasize the current facilities provided by these instruments to the information societies and determine the recent exhibitions organized which could be taken as a reference by the museums in our country (Turkey). In that line of discussion, first chapter refers to the transformation experienced by the museum exhibitions after 1980. Following the chapter touching the characteristics of the information societies and one of the recently popular generation classifications $(X, Y$ and $Z$ generations), data obtained through observation during field researches are presented. After the chapter providing the photos of expositions organized by the European museums between 2012 and 2017, a general evaluation is made. In this general evaluation made in the conclusion section of this study, determinations and deductions coinciding with the purposes of the research are made in the light of the data collected.
\end{abstract}

Keywords: Museology, Museum Management, Exhibition, Exposition, Exposition Technologies. Received: 11.06 .2019

Accepted: 26.08.2019

\title{
Suggested Citation:
}

Boyraz, B. (2019). A Study on Actual Exposition Technologies Used in European Museums, Journal of Social, Humanities and Administrative Sciences, 2(8): 532-562.

(c) 2019 Sosyal, Beşerî ve İdari Bilimler Dergisi. 


\section{Gíriş}

T. Atagök'ün ifadesi ile müzeler; yaratıcılık, mantık, gözlem, hayal gücü ve beğeni duygularının oluşup gelişmesine katkıda bulunan yaygın eğitim kurumlarıdır (Atagök, 1999: 223). Ayrıca müzeler kişileri içinde bulundukları toplumlar üzerine bilgilendiren (Kurak Açıcı ve Konakoğlu, 2018: 671) ve kültürler arası paylaşıma olanak sağlayan platformlardır (Şahan, 2005: 498). Bugün müzelerin; sosyalleşmenin dijitalleştiği ve bireysel alışkanlıkların değiştiği bir ortamda günceli yakalamak için çaba gösterdiğini söylemek mümkündür. ${ }^{2}$ Söz konusu çabanın açıkça gözlemlenebildiği müzecilik işlevlerinden ${ }^{3}$ biri sergilemedir. ${ }^{4}$

Nadire kabinelerinden, (Avrupa) kraliyet koleksiyonlarının kamuya açılmasına (18.yy) kadar derin bir geçmişi bulunan sergileme işlevi, kullandığı yöntemler ${ }^{5}$ açısından 20.yy ile birlikte radikal sayılabilecek bir dönüşüm göstermiştir. ${ }^{6} \mathrm{Bu}$ dönüşümün ortaya çıkış sebeplerine dair genel kanı; Birinci ve İkinci Dünya Savaşları (1914-18 / 1939-45) sonrasında beliren "kültürel gelişmelerin, felsefi çıkarımların ve sıra dışı sanat yapıtlarının" sergi mekânlarının sorgulanmasına neden olduğu ve bu durumun da yeni bir vizyona gereksinim duyurduğu üzerinedir. Ancak günümüz perspektifinden bakıldığında mevzu bahis dönüşüme dair sebeplerin sadece bunlardan ibaret olmadığı görülebilir. Daha geniş kapsamlı bir değerlendirme için bir dizi gerekçe sunulabilir. İlk akla gelenler şunlardır;

a) 20.yy'ın ikinci yarısındaki sanat akımları7 "estetik" konusunda tartışmaya açık bir süreç başlatmış, müzeler de bu süreçte koleksiyonlarına "anlam yönünden katmanlı ya da protest eserler" katmıştır. Aynı müzeler ziyaretçilere bu nesnelerin alt metinlerini açılamak için ("Beyaz Küp" olgusu ile zıtlaşmayacak nitelikte)

\footnotetext{
${ }^{2}$ C. Karadeniz'in yakın zamanlı araştırmasında müzelerin güncel girişimleri hakkındaki ifadesi şu şekildedir; “21. yüzyılda demokratik, topluma açık ve toplum katılımına olanak sağlayan, toplum için ve toplumla birlikte var olmayı amaçlayan müzelerin felsefe, misyon, vizyon, amaç ve işlevlerini toplumsal çalışmalar doğrultusunda geliştirme çabaları birbirini izlemektedir" (Karadeniz, 2017: 19). B. Okan'a göre de mevcut toplumsal yapının ışı̆̆ında çağdaşlaşma sürecindeki müzeler; kitle iletişim araçları, eğitim programları ve sosyal etkinliklerle izleyiciye ulaşabilecekleri yeni bir müzecilik anlayışını benimsemiştir (Okan, 2015: 189).

${ }^{3}$ Bkz. Müzeciliğin beş temel işlevi; Araştırma, Bakım-Koruma, Belgeleme, Eğitim ve Sergileme.

4 "Sergi" ve "sergileme" kavramları arasındaki farkı belirtmek gerekir. Türk Dil Kurumu'nun her iki kavram için de açıklaması mevcuttur. Buna göre sergi; "Halkın gezip görmesi, tanıması için uygun biçimde yerleştirilmiş ürünlerin, sanat eserlerinin tümü" anlamına gelmektedir (TDK, 2018). Sergileme ise; "sergilemek işi, teşhirdir" (TDK, 2018). B. Ayan Ergen'e göre de sergi; sahip olunanları gerek göstermek gerekse ticaret amacıyla başkalarına sunmak için oluşturulan bir düzenken, sergilemek eski kullanımıyla yine teşhirdir (Ayan Ergen, 2013: 130). Anlaşılabileceği üzere sergi ve sergileme birbirleriyle ilişkili olmalarına karşın farklı durumlardır. Bu ayrımı net biçimde ifade etmek için sergiyi; nesnelerin bilinçli bir kurgu eşliğinde belirli mekânlar dâhilinde ziyaretçiye sunulması olarak, sergilemeyi de; sergi için gösterilen girişimlerin bütünü olarak tanımlamak mümkündür.

5 "Sergi" ve "sergileme" arasındaki farka açıklık getirmiştik. Sözü geçen "sergileme yöntemlerinin" sergi için gösterilen teknik girişimlerin çeşitliliğine, "sergileme araçlarının" da bu çeşitlilik içinde kullanılan ekipmanlara işaret ettiği söylenebilir.

${ }^{6}$ Kendi dönemine göre farklı bir estetiğe hitap eden üretimler hedefleyen Bauhaus Okulu'nun (1919-1933) sergi ve fuarlar için hazırladığı tasarımlar ilgili yüzyıldaki değişimin göstergeleri arasında sayılmaktadır. Ç. Demir'in aktardığı şekli ile; Grafik tasarımcıların, sergileme tasarımına değişik örnekler sunmaları 1920'lerin ortasına denk gelirken, Bauhaus Okulu öğrencilerinin sergileme araçları için yaptığı tasarımlar ve deneysel nitelikteki üretimler bu alana farklı bir bakış açısı kazandırmıştır (Demir, 2008: 53).

${ }^{7}$ En başta 1960'lı yıllardan sonra beliren akımlar.
} 
alternatif yollar aramış, küratörler sunum konusunda uzman tasarımcılar 8 ile işbirliği yapmıştır. ${ }^{9}$

b) Müzeciliğe direk ya da dolaylı yoldan temas edip, etik konusunda çerçeve çizebilen uluslararası komiteler ${ }^{10}$ müzenin sergileme işlevine yönelik yenilikçi yaklaşımları ve söz konusu yaklaşımları ilgilendiren araştırmaları teşvik etmiştir. Buradan hareketle değerlendirmeye açllan sergileme işlevi ve üstlendiği misyona dair farklı öneriler belirmiştir.

c) Eğitim bilimlerindeki araştırmalar, deneyimlemeyi güncel perspektifler ile mercek altına almaya başlamıştır. Bu sayede deneyimlemenin öğrenmedeki kazanımları sık sık gündeme gelmiş, kullanımı yaygın biçimde kabul görmüş ve müzelerdeki yeri genişlemiştir.

d) E. Şar ve T. Sağkol'a göre; "Müzecilik kavramının ve dolayısıyla müzelerin, toplumların yapilanmasinda ve toplum kimliğinin oluşmasında son derece önemli bir rol oynadı̆̆ şüphesizdir" (Şar ve Sağkol, 2013: 84). Bilgi toplumlarında ve bu toplumlara özgü olan bilgi ekonomisinde bu role yeni sorumluluklar yüklenmiştir. Artık bilgi için veri toplayan ve bunu enforme eden kurumlar olarak anılmaya başlayan müzeler, sergileri için toplumsal gelişmeleri daha yakından takip etmeye ve geniş kapsamlı düşünüp yenilikçi adımlar atmaya yönelmiştir.

e) 20.yy'a bir bütün olarak baktığımızda, sürecin başından sonuna kadar ziyaretçilerin yani hedef kitlelerin ihtiyaçları ve alışkanlıkları değişmiştir. Müzeler, müze hamilikleri bulunan vakıflar ve müzeler ile yakından ilgilenen sivil toplum kuruluşları hedef kitlelerin değişen ihtiyaç ve alışkanlıklarını analiz etme çabasına girmiştir. Edinilen bilgiler müzelere gerek eğitim gerekse sergileme konusunda kılavuzluk etmiş, isabetli politikalar hazırlanmasına yardımcı olmuştur.

f) İçerik yönünden belirli bir doygunluğa sahip olan ve müzecilik disiplinini yakından ilgilendiren; enstitülerin, akademik eğitim programlarının, sempozyumların ve çalıştayların sergilemeye temas eden teknik bilgi içerikli çıktıları (bulguları, önerileri, sonuç bildirgeleri vb.) sahada yankı bulmuştur. Bu çıktılar tıpkı hedef kitle analizleri gibi yönlendirici bir etki yaratmıştır.

g) Teknolojide, en başta da iletişim teknolojilerinde ilerlemeler yaşanmıştır. $\mathrm{Bu}$ ilerlemeler eşliğinde bünyesine dijital altyapıyı entegre eden kurum sayısı günden güne artmıştır. Müzeler de bu süreçte geri planda kalmamıştır.

h) Müzelere fayda sağlama amacı güden inovatif öneriler ve deneysel nitelikteki bağımsız girişimler çoğalmıştır. ${ }^{11}$

\section{ARAŞTIRMANIN AMACI}

Sıraladığımız gerekçeler çoğaltılabilir. Ancak sadece üsttekiler üzerinden bir çıkarımda bulunduğumuzda bile 1980'lerden günümüze kadar olan periyodun "özel” bir süreç olduğunu ifade etmek yanlış olmaz. Bu periyot dahilinde müzeler sergileme konusunda keskin adımlar

\footnotetext{
${ }^{8}$ K. Sakarya'nın ifadesiyle; "Sergilemelerde izleyicinin görmek istediği objeyi ilgisini daha çok uyandıracak tasarımla sunmak, tasarımcının becerisine bağhıdır. Kullanılan malzemelerin seçimi kadar, uygulamada tercih edilecek yöntemler de oldukça etkilidir" (Sakarya, 2018: 124). Bu bağlamda sergi tasarımlarıyla ilk defa ün kazanan tasarımcı herhangi bir mimari alt yapısı olmayan fakat Britanya Festivali'ndeki sergileme yaklaşımı ile dikkat çeken James Gardner'dır (Demir, 2008: 53).

${ }^{9}$ A. Kurşuncu sanatçı, sanat yapıtı ve sergileme ile ilgili olarak bir noktanın altını çizmiştir: "Sanatın üretilmesi tamamen sanatçının kendi zihninden başlayan yalnız bir yaratım süreciyken, sergilenmesi sanatçıdan bă̆ımsız birçok kişinin dâhil olduğu bir etkinlikler zinciridir" (Kurşuncu, 2019: 44).

${ }^{10}$ Bkz.: ICOM, UNESCO vb.

${ }^{11} \mathrm{Bu}$ maddede müze uzmanlarının, küratörlerin, tasarımcıların, sanat tarihçilerin ve eleştirmenlerin müze sergilerine odaklanan bağımsız girişimleri (kişisel gayretleri) ifade edilmektedir.
} 
atmış, teknolojiden destek alan girişimler de bu adımlarda ön plana çıkmıştır. ${ }^{12}$ Araştırmanın amacı da özellikle 1980 sonrası girişimlerin günümüzde ulaştığı noktayı ölçecek biçimde şekillenmiştir. Temel amaç güncel sergileme teknolojilerinde öne çıkan araçları tespit etmektir. $\mathrm{Bu}$ amaca ulaşıp, genel bir değerlendirme yapmak için üç hedef belirlenmiştir.

a) Hedeflerden ilki; Avrupa müzelerinin (özellikle $Y$ ve $Z$ kuşağını ${ }^{13}$ ilgilendiren) dijital bağımlılı̆̆a hitap edebilecek sergileme teknolojilerini kullanmadaki girişimlerini yerinde gözlemlemektir.

b) İkincisi gözlemler 1şı̆̆ında güncel sergileme teknolojilerinin ${ }^{14}$ sunduğu yeni hizmet ve olanakları irdelemektir.

c) Üçüncüsü ise toplanan veriler üzerinden, yenilikçi sergileme teknolojilerinde ülkemiz (Türkiye) müzelerinin referans alabileceği yakın dönemli sergileri (veya bu sergileri organize eden müzeleri) saptamaktır.

\section{ARAŞTIRMANIN KAPSAMI}

Araştırmanın coğrafi kapsamı: köklü müzelere sahip olması, müzecilik çalışmalarında nitelikli girişimlere ev sahipliği yapması ve sergileme teknolojilerinin yaygın kullanımı nedeniyle Avrupa kıtasıdır.

İncelemeler kıtanın her iki kanadında; Batı ve Doğu Avrupa'da bulunan ülkelerde, kalabalık nüfuslu şehirlerdeki müzelerde yapılmış, tüm veriler 2012-2017 arasındaki beş yıllık zaman diliminde edinilmiştir. Ziyaret edilen ülkeler, şehirler, müzeler ve ziyaret yılları sırasıyla şu şekildedir (Bkz. Tablo 1);

Tablo 1. Araştırma İçin Ziyaret Edilen Ülkeler, Şehirler, Müzeler ve Ziyaret Yılları

\begin{tabular}{|c|c|c|c|c|}
\hline Sira & Ziyaret Edilen Ülke & Ziyaret Edilen Şehir & Ziyaret Edilen Müze & Ziyaret Edilen Yıl \\
\hline 1 & Fransa & Strazburg & Strazburg Tarih Müzesi & 2012 \\
\hline 2 & Sirbistan & Belgrad & $\begin{array}{l}\text { Sirbistan Tarih Müzesi ve } \\
\text { Nikola Tesla Müzesi }\end{array}$ & 2017 \\
\hline 3 & Yunanistan & Atina & $\begin{array}{l}\text { Akropolis Müzesi ve Kiklad } \\
\text { Sanat Müzesi }\end{array}$ & 2017 \\
\hline 4 & Hirvatistan & Zagreb & $\begin{array}{l}\text { Zagreb Çă̆daş Sanatlar Müzesi } \\
\text { \& Zagreb Tarih Müzesi }\end{array}$ & 2017 \\
\hline 5 & Almanya & Hannover & Aşağı Saksonya Eyalet Müzesi & 201715 \\
\hline
\end{tabular}

\footnotetext{
12 İlgili periyodun getirilerine ve bunların müzeler üzerindeki etkisine dair dikkat çeken görüşler mevcuttur. C. Çoşkun'un H. Michael'den aktardığı şekliyle; "1980'li yıllardan itibaren yoğun bir şekilde hayatı etkilemekte olan dijital dönem bir yandan yeni algılama biçimleri üretmekte, bir yandan da, gerek var olan, gerek de türemekte, evirilmekte olan söz konusu algılama biçimlerinin ifadesinde yeni olanaklar getirmektedir" (Çoşkun, 2017:62). O. Boratav ve N. Gürdal da teknolojinin gündelik hayata en yoğun biçimde kanalize olduğu 1980'ler sonrası için bir tespitte bulunmuştur. Bu tespite göre; "1980 sonrasındaki dönemde hızla gelişen teknoloji, birçok sanatçının dikkatini çekmiş, ve etkisi altına almış, ifade ve üretim biçimlerini de değiştirmiştir. Bu uzun değişim surecinde müze, seçkin azınlı̆̆a hitap eden havasından uzaklaşmış, her yönden gelişen teknolojiye ayak uydurmaya başlamış, sanal müzelerin gündeme gelmesiyle dünya çapında erişim ve iletişim sağlanmıştır" (Boratav \& Gürdal, 2016: 169).

13 1.3. Hedef Kitle Gruplarındaki Değişim başlığı altında bu kuşaklar açıklanacaktır.

${ }^{14}$ H. R. Alpay'ın aktardığı şekliyle terimsel olarak teknoloji "bilginin eyleme geçirilmiş halidir" (Alpay, 1989: 19). Burada eylemden kasıt belirli bir bilgi birikimi ile oluşturulan ve fayda sağlamak amacıyla kullanılan üretimdir. Araştırma kapsamındaki sergileme teknolojileri ifadesi bir takım ihtiyaçlar doğrultusunda sergileri desteklemek amacıyla üretilen (veya sergilere uyarlanan), dijital altyapılara sahip olup, etkileşimsel özellikler de taşıyabilen araçları gruplamak için kullanılmıştır. (Belirtmek gerekir ki etkileşimsel özelliğe sahip araçların hepsi teknolojik altyapıya sahip olmayabilir. Etkileşimsellik ve teknoloji birbirinden ayrı kavramlardır).

${ }^{15}$ Almanya' daki müze ziyaretleri 2017 sonunda başlamıştır. Ancak inceleme süreçlerinin bir kısmı 2018'e de sarkmıştır.
} 


\section{ARAȘTIRMANIN YÖNTEMI}

İlgili veriler saha araştırmaları sırasında gözlem metodu ile toplanmış ve toplanan verileri görsel yönden desteklemek için sergilemeler fotoğraflanmıştır. Kavramsal çerçeveyi hazırlamak ve verilerin sunumu / analizi öncesinde konuya dair kuramlara / görüşlere yer vermek için ise literatür taramasından yararlanılmıştır.

\section{SERGILLEME IŞSLEVININ 1980 SONRASINDAKİ DÖNÜŞÜMÜ ÜZERINEE BİR DEĞERLENDİRME}

Sergileme teknolojilerinin yakın zamanlı durumunu etüt etmek için öncelikle 1980'lerden başlayan bir arka plan incelemesi yapmak gerekir. Bu anlamda belli başlı anahtar kelimelere temas eden bir yol izlenebilir. Giriş kısmında sergilemenin 20. yy içindeki dönüşümünün altında yatan gerekçelere dair bir maddelemeye yer vermiştik. Bu maddelemede yer bulup, teknoloji ile yakından ilgili olan; "deneyimleme, iletişim araçları, bilgi toplumları ve hedef kitleler" belirli çıkarımlar eşliğinde ilerlememize yardımcı olacak anahtar kelimelerdir.

Bilindiği gibi 20.yy'ın ikinci yarısında; sanat yapıtı ve sergi mekânı birlikte düşünülmüş, özellikle 1960 sonrasında sanat nesnesi ve mekân ilişkisine bütüncül biçimde yaklaşan eserler türemiştir. ${ }^{16}$ Antik Yunan'daki ilham perilerine atıfta bulunan bir isme ${ }^{17}$ sahip olan müzeler de bu girişimlere kayıtsız kalmamıştır. Müze koleksiyonları entelektüel bir açılım yaparak "yeni eserleri” kabul etmeye başlamıştır. Malzeme yönünden zengin, kavramsal açıdan da katmanlı olan eserlerin kayda geçirilmesi ile envanter defterleri çeşitlenmiş ve koleksiyonların alt metinleri güncellenmiştir. Ancak bu durum bir takım tartışmaları da beraberinde getirmiştir. Eğitimden, bakım ve korumaya, pek tabii olarak da sergilemeye kadar uzanan bu tartışmalar genellikle müzecilik ile ilgili mecralarda vuku bulmuştur. Bunlardan sergileme ile ilgili olanlar arasında ziyaretçi odaklı yeni öneriler sıklıkla etüt edilirken, ana gündemlerden biri; ICOM'un kavramsal oturumlarında da dile getirilen "toplumsal ihtiyaçların güncellenmesi" konusudur. Müzelerin barındırdıkları koleksiyonları, fayda sağlamakla mükellef oldukları toplumların değişen ihtiyaçları doğrultusunda sergileyip sergileyemeyeceği üzerine şekillenen bu gündem o vakitler geniş yankı bulmuştur. ${ }^{18}$ İleri sürülen öneriler hâlihazırda etüt edilen "ziyaretçi merkezli müzecilik" ${ }^{19}$ yaklaşımının derinleşmesine yol açmıştır. ${ }^{20}$ Bahsi geçen yaklaşımın çıktılarını benimseyen müzeler de 1980'lerle anlık kazanımların ötesini düşünen sergileme politikalarına yönelmiştir. Bu noktadan sonra; araştırma yapmak, entelektüel seviyenin artmasına yardımcı olmak ve bilime destek vermek gibi görevlerini de geri planda bırakmayan müzeler, sergilerinin

\footnotetext{
${ }^{16}$ B. Çolak süreci şu şekilde betimlemektedir: "1960 sonrasında gelişen süreçte yapıtın sergilenmesinde; çerçevenin dışlanması, resim yüzeyinin sergi mekânının duvarlarılla ilişkiye girmesi ve böylece galeri mekânının kendisinin resmi çerçeveleme işlevini yerine getirmesi önemli birer değişim olarak kabul edilir. Bu anlamda modernizm içerisinde minimalist, yapıtın biçimsel özelliklerinin vurgulanmasına olanak tanıyan, eserin algılanma sürecinde kendisinden başka dikkat çekici her türlü unsurdan soyutlanmıs sergi mekânı; yapıtın izlenmesinde ve algılanmasında sanat eserine odaklı bir yaklaşımı beraberinde getirir" (Çolak, 2011: 44).

${ }_{17}$ Bkz. Muses ve tapinakları Mouseion.

181974 yılında ICOM tarafından bir müze tanımlaması yapılmıştır. Bu tanımlamanın ardından da müzenin toplum içindeki misyonu sıkça tartışma / yorumlama konusu olmuştur. Ö. Kandemir ve Ö. Uçar bu tartışmaları / yorumlamaları Değişen Müze Kavramı ve Çağdaş Müze Mekânlarının Oluşturulmasına Yönelik Tasarım Girdileri adlı araştırmalarında geniş biçimde ele almıştır. Bu noktada söylenebilecek şey müzecilik kavramının çeşitlilik kazanmaya devam ettiği ve toplumsal özellikler bağlamında kendini yenilemeye çalıştığıdır.

${ }^{19}$ A. Acar' a göre; “Ziyaretçi odaklı modern müzecilik anlayışı, müzelerin birer bilim enstitüsü olarak da ziyaretçilerin eğitimi üzerine yoğunlaşmalarına kapı açar. Artık müzeler, sergilerinde ilettikleri mesajın müze kullanıcısının hayatında oluşturduğu artı değeri sorgulamakta; bilginin algılana bilirliğini arttırmaya yönelik çalışmalar gerçekleştirmekte, izleyici deneyimlerinin geribildirimlerini de birer veriye dönüştürebilmektedir" (Acar, 2017: 3).

${ }^{20}$ Benzer bir değerlendirmeyi Z. Aykut da yapmıştır: "20. yüzyıl ile birlikte geleneksel müzecilik anlayışından uzaklaşarak birer eğitim merkezine dönüşen müzelerde, sergileme mekânlarının yeni bir gelişim surecini başlattı̆̆̆ izlenmektedir. Koleksiyonların sergilemesini daha etkili gösterebilmek ve ziyaretçilere mesajı ulaştırabilmek amacıyla hikâyeleri ile birlikte anlatımın daha çok benimsendiği ve "nesne odakh sergilemeden ziyaretçi odaklı sergilemeye" doğru geçisin olduğu görülmektedir" (Aykut, 2017: 2019).
} 
"deneyimleme" ve "iletişim" yönlerini her zamankinden daha fazla göz önünde bulundurmuştur.

\subsection{Deneyimleme ve İletişim Araçlarının Dönüşümdeki Rolü}

Bilgiyi aktarmak için deneyimlemeyi ön plana alan sergileme vizyonunun altında yatan düşünceyi $A$. Acar şu şekilde ifade etmiştir: "Artık müzenin verdiği bilgi, müze duvarlar içinde nötr düzlemlerinde sabitlenen eserlerden çok, müze ziyareti sırasında ve sonrasında, anlatımı deneyimleyen kullanicıda hayata gecen imgeler kümesidir" (Acar, 2017: 3). Deneyimlemeyi etraflıca etüt eden müzeler anlık kazanımların ötesine geçip daha geniş bir sürece yayılan bu olguyu neredeyse tüm alanlarında tatbik etme çabasına girmiştir. ${ }^{21}$ Deneyimleme ile sergilemenin işlevselliği artmış, etkileşim ${ }^{22}$ özelliğine sahip uygulamalardan da daha fazla yararlanılmaya başlanmıştır. ${ }^{23}$ Böylelikle ziyaretçiler müze içinde "etken" konuma geçmiş, sergilemeler de "edilgen" materyaller kazanmıştır. Bir diğer husus olarak, ortaya çıkan yeni vizyon ile sergiler iletişim konusunda kurumsal iletişimle bağlantılı uygulamalar halini almıştır. Bu gelişmenin en önemli katkısı iletişim araçlarından ve bu araçların sahip olduğu teknolojilerden azami düzeyde faydalanmaya başlamak olmuştur. ${ }^{24}$ Gelinen noktada deneyimleme sergilemede ne kadar dikkate değer bir yer edindiyse, mesajı kaynaktan alıcıya iletmekte son derece etkili ve ivedi olan iletişim araçları da o kadar yer edinmiştir.

Müzeler sergileme için başlarda iletişim araçlarının görsel ve işitsel niteliklerinden yararlanmıştır. 1990'larla birlikte video sanatı üretimlerinin artan kalitesi ve sesli anlatımın kazandığı mobil kabiliyetler müzeleri televizyon tipi monitörlere ve sesli rehberlere daha fazla yatırım yapmaya yönlendirmiştir. Gerek ziyaretçi geri bildirimlerinin olumlu olması, gerekse küratörlerin bu tür araçları benimsemesi ile de diğer duyuların dikkate alındığı sergileme yöntemlerinin önü açılmıştır. 20.yy'ın sonlarında iletişim araçlarının alt yapısından destek alan ve dokunma duyusu ile ilişkili olan teknolojilerin sergi salonlarında karşımıza çıkması sıklaşmıştır. Hatta deneysel biçimde olsa bile diğer duyulara yönelik girişimler de baş göstermiştir (Bkz. Koku duyusu). Bu durum sergilemeye yeni bir boyut kazandırırken, sürece katkı sağlama potansiyeli taşıyan araştırmalar kültür kurumlarınca teşvik edilmiş, teknoloji transferleri ile müzelerde kullanılabilecek iletişim araçlarının skalası genişlemiştir.

Müzeler 2000'li yıllardan sonra teknoloji ile iyiden iyiye içli dışlı olmuştur. Fakat milenyum

\footnotetext{
${ }^{21}$ Deneyimlemenin müzelerdeki yerini kavramak için Ö. Kandemir ve Ö. Uçar' 1 n sözlerine de yer verilebilir: “Çağdaş Müze olgusu, geçmişten gelen gereksinimler ile ziyaretçiye yönelik yeni ihtiyaçları karşılama çabasında, teoriye ve pratiğe yönelik köklü değişimleri barındırmaktadır. Bu değişim müzenin, yükümlü oldŭ̆u eylemleri kullanıcı deneyimine odaklanan, çok katmanlı zengin ortamların yaratılmasımı hedefleyen bir yaklaşımla yerine getirmesini gerekli kılmıştır. Bu doğrultuda dış mekandan iç mekana, karşılama mekânından, sirkülasyon alanlarına, sergi mekânlarından çok amaçl salonlara, atölyelerden laboratuvarlara, restoranlardan satış birimlerine tüm mekânlar, deneyime dayah ortamların yaratılması hedefiyle, objenin, mekânın ve de en temelde ziyaretçinin bir araya getirildiği bütünleşik bir yaklaşımın sonuç ürünü olarak ortaya konulmaktadır" (Kandemir ve Uçar, 2015: 43).

22 Y. Keş ve A. Başer Akyürek interaktivite ifadesiyle etkileşimselliğin günümüz müzelerdeki yerine şu şekilde dikkat çekmiştir; "Küreselleşen dünyada hayatın her alanında yaşanan değişiklikler, insanla ilişki içerisinde olan tüm birimlerin kendilerini yenilemeleri gereksinimini ortaya çıkarmışır. Bu bağlamda yenilenmeye ihtiyaç duyan birimlerden biri olan müzelerin kullanabileceği modern yaklaşımlardan biri de interaktivitedir" (Keş ve Başer Akyürek, 2018: 96).

${ }^{23}$ Müzenin bu noktadaki girişimi şu şekilde açılanabilir; “Müze bir sergi nesnesi ile ilgili bilgi verme ya da deneyim kazandırma amacı ile bir uygulama yapıyor. Uygulama gerçekleştirilirken de öğrenmede ya da deneyim kazanmada etkili bir yol olduğunu düşündüğ̈̈ etkileşimsellik kullanılıyor. Böylece ziyaretçi teknoloji yardımıyla oluşturulmuş etkileşimsellik ile nesneye yönelik bir deneyim kazanıyor" (Boyraz, 2011: 27).

24 20.yy sonlarında teknolojinin değişim ve gelişim adına yakaladığı ivme iletişim konusunda dijital alt yapıya sahip araçlara üstünlük kazandırmıştır. Bu araçlar sayesinde bilginin kaynaktan alıcıya ulaşması hızlanmış ve pratikleşmiştir. Matbu haldeki bilgilerin elektronik ortamlara aktarılmaya başlaması ile de bilgi artık dijital sahalarda işlenmeye başlamıştır. Beliren bu ufuk kamusal alanlarda olduğu gibi müzeleri de ilgilendirir hale gelmiştir.
} 
toplumları bilgi kaynağına yönelmede önceliği tek bir araca, internete vermiştir. Başlarda sinırlı bir gruba; güvenli ve hızlı iletişim kurma olanağı sağlamak amacı ile oluşturulan internet kısa sürede kitleleri kapsayabilen geniş bir ağa ulaşmıştır. ${ }^{25}$ Bilgiye erişim imkânı tanırken kendine özgü ara yüzlerden yararlanan internet, zaman geçtikçe kullanıcıları üzerinde iz bırakan bir (dijital) hareket kabiliyeti kazanmıştır. Bu durum kendine has özellikler barındıran "internet kültürünü" doğurmuş ve müzeler de sergilemeleri nezdinde internet kültürünü göz önüne almak durumunda kalmıştır. Hâl böyleyken sergileme teknolojileri ziyaretçilerin interneti kullanım alışkanlıklarından referanslar alan işlevler ${ }^{26}$ kazanmaya başlamıştır. 2010 sonrasındaki sergilerde görülen; tabletlerin ve kioskların ara yüzleri ve kontrol mekanikleri sıradan bir internet kullanıcısının kolaylıkla kavrayabileceği niteliklere ulaşmışır. ${ }^{27}$ İnternetin ardından hangi teknolojinin hangi "hedef kitle grubuna" uygun olduğu sorusu iyice ön plana çıkmıştır. ${ }^{28}$ Fakat mevzu bahis soruyu irdelemeden önce (yukarıda anlattıklarımız ile ilgisi nedeniyle) değinilmesi gereken bir konu daha mevcuttur. Bu konu "bilgi toplumları" konusudur. ${ }^{29}$

\subsection{Bilgi Toplumları ve Kazandıkları Yeni Alışkanlıklar}

Sanayi Devrimi'ni izleyen süreçte sermaye ve iş gücünün yerini bilgi almış, toplumsal örgütler de önemi artan bu yeni kavrama göre şekillenmeye başlamıştır. N. Güçlü ve K. Sotirofski'nin belirttiği gibi; mevzu bahis yeniden yapılanmada bilgi ile onu iletmekte kullanılan sembollerin üretimi dağıtımı güncellenmiş, enformasyon değer kazanmış ve bilgi ileri ekonomilerin merkezi haline gelmiştir (Güçlü \& Sotirofski, 2006: 352). Alana dair literatürde sıkça bahsi geçen bu toplumları araştırma kapsamımız ile örtüşen bir çerçeve ile ele almak gerekir. Dolayısıyla değerlendirmeyi yakın zamanlı bir perspektif ile Avrupa kıtası üzerinden yapmak daha uygun olur.

1990'ları izleyen süreçte, Avrupa Birliği'nin genişleme politikalarını takiben kıtada yeni bir hareketlilik başlamıştır. Birliğe aday ve aday adayı ülkeler kendi toplumlarının gündelik yaşamını ilgilendiren hemen her alanda birlik kriterlerine uygun politikalar izlemeye yönelmiştir.

Otoritelerini 21.yy'a taşıma hedefindeki kurucu ve üye devletler ise sürdürülebilir kalkınma konusunda bilgi merkezli ekonomilere odaklanmış ve bilgiye dayalı uzmanlık sahaları bu toplumlarda yeni istihdam alanları açmıştır. Verinin enformasyona dönüşümünden ve enformasyonun da kamu faydası için kullanımından feyzler alan yeni istihdam alanları Avrupa'nın 2000'lerde sahip olduğu teknoloji vizyonunu betimleyecek göstergelerdir. Fakat teknoloji gündelik yaşama dâhil olurken kıtadaki toplumların yapı taşları bireyler de yeni alışkanlıklar edinmiştir. 2000'li yılların başında Avrupa'da görüntülü mobil teknolojilerinin kullanımı belirli bir ekonomik güce sahip kesimin elindeyken, 2010 sonrasında; tabletler, akıllı

\footnotetext{
${ }^{25}$ B. Yılmaz'ın ifadeleri ile. "Son yıllarda bilgi teknolojileri alanında sözü en çok edilen gelişme kuşkusuz internettir. İnternet, sağlıklı ve güçlü bir bilgi-toplum ilişkisi surecinde yeni bir aşamayı ifade etmektedir. Gerekli koşullar, diğer bir deyişle eğitimsel, kültürel ve teknolojik altyapı sağlandığında hemen her alanda yeni olanaklar yaratan bu araç toplumlar için geleceğe hazırlanmanın yeni bir mücadele alanı olmuş gibi görünmektedir" (Yılmaz, 2002: 111).

${ }^{26}$ Görsel ağırlıklı iletişimi benimseme, arama motoru butonuna sahip olma ve aranan kelimeleri hafızada tutma gibi.

${ }^{27}$ Günümüz sergileme teknolojileri bilgiye hızlı ve kesintisiz biçimde erişim sağlamak için özünde internet için kurulan dijital altyapıdan faydalanmaktadır. İnternet üzerinden sağlanan bağlantı birden fazla sergileme teknolojisine eş güdümlü biçimde hareket etmek imkânı tanırken müze için de total bir "bilgi edinme" mekanizması sunmaktadır.

${ }^{28} R$. Küçükerdoğan hedef kitlelerin belirlenmesi adına şu ifadeleri kullanır: "... Hedef kitlenin tanımlanmasında ele alınması gereken ölçütler de bulunmaktadır. Fiziksel ve toplumsal-ekinsel ölçütler. Hedef kitlenin yaşı, cinsiyeti, uğraşı, yaşadığı yer, ailesi ile ilgili nüfus bilimsel (demografik) bilgiler ve ilgi alanları ve tüketimleriyle ilgili bilgiler fiziksel ölçütleri oluşturur. İkinci grup ölçütler içsel ölçütlerdir. Bunlar aynı demografik toplulukta bulunan kişiler arasındaki yaklaşık nicel farkllıkların belirlenmesi ilkesine dayanan ve sonuçta hedef kitlenin yaşam biçimini, gereksinimlerini, benimsediği değerleri, ruhsal özelliklerini ortaya çıaran ölçütlerdir"(Küçükerdoğan, 2012: 330).

${ }^{29}$ Bilgi toplumları sanayi toplumlarından farklı olarak "bilgi ve nitelikli insan" olgularını merkeze alan toplumlardır.
} 
telefonlar, sanal gerçeklik gözlükleri ve hatta giyilebilir ekipmanlar hemen her kesim ve yaş grubu tarafından benimsenmiştir. Bu durumun bir uzantısı olarak birbirlerine yakın zamanlı kuşaklar arasında; sosyal medya, uygulama (aplikasyon) ve oyun bağımlılıkları gibi alışkanlıklar baş göstermiştir. ${ }^{30}$

Üstteki değişimleri gözlemleyen müzeler sergileme konusunda pratik yaparken, bilgi ekonomisinin getirilerine aşina olan hedef kitle gruplarının artık klasik sergileme materyallerinden (Bkz. Gösterişli vitrinler, uzun bilgiler içeren etiketler, posterler vb.) yararlanan sergilere ilgi göstermediğini fark etmiştir. ${ }^{31}$ Dolayısıyla sergilemelerinde teknolojiye yönelmiş, kullanacakları teknolojileri seçerken de dijital alışkanlıkları, diğer bir deyişle "teknoloji tüketimini" dikkate almaya başlamışlardır.

Bu noktada tekrar hangi teknolojinin hangi "hedef kitle grubuna" uygun olduğu sorusuna dönülebilir.

\subsection{Hedef Kitle Gruplarındaki Değişim}

Teknoloji tüketiminin özünde neyi ifade ettiği ve bilgi toplumlarındaki hedef kitle gruplarının ne gibi özelliklere sahip olduğunu açıklamak için kuşak farklılıklarını ${ }^{32}$ göz önünde bulunduran popüler bir yaklaşımdan yararlanılabilir. Günümüzde yakın zamanlı olmalarına karşın her biri kendine özgü nitelikleri bulunan kuşaklar için $X, Y$ ve $Z$ harfleri ile ifade edilen bir gruplama mevcuttur. 20.yy'ın ikinci yarısından 21.yy'ın ilk çeyreğine kadar doğanları kapsayan ve mevcut teknolojiler ile tanışma fırsatı yakalayan bireylere işaret eden bu kuşak gruplamasında; $X$ kuşağ 1 1965-79 arasında doğanları, Y kuşağı 1980-99'dakileri ve $Z$ kuşağı da 2000 sonrası doğumluları ifade etmektedir.

Bu üç kuşağın özellikleri referanslar eşliğinde açıklanabilir.

H. Y. Taş ve S. Kaçar, X kuşağının özelliklerini şu şekilde ifade etmiştir; "1965-1979 yılları arasında vuku bulan gerek siyasi gerekse de ekonomik krizler X Kuşă̆ı doğrudan etkilemiştir. X Kuşağı, kendilerinden önce gelen Bebek Patlaması Kuşağı üyelerinin gençlik dönemlerinde yaşanan 68 Kuşağı'nın etkisinde kalmışlardır. Ayrıca, Türkiye tarihinde politik suskunluk dönemi olarak ifade edilen 1980 Askeri Darbesi'ni yaşamışlardır. İki büyük siyasi olayın arasında kalmışlardır. Dolayısıyla dünya üzerinde ekonomik ve sosyal temellerin değiş̧imi bakımından "Geçiş Dönemi Kuşă̆ı", ağır siyasi koşullar bakımından ise "Kayıp Kuşak" olarak bilinmektedirler" (Taş ve Kaçar, 2019: 647).

$Y$ kuşağını tanımlamak için ise M. U. Tuncer' in görüşleri aktarılabilir; “Y kuşağı 1980'lerden 2000'li yıllara kadar doğan bireyleri kapsamaktadır. X kuşağından farklı olarak $Y$ Kuşă̆ı teknolojik dönüşümün tam içinde var olmuştur. Ergenlik dönemlerinde cep telefonları ile tanışmış bu kuşak daha bireycidir aynı zamanda iş yaşamında da hızla yükselmeye odaklanmıştır. Çalışmaktan çok kazanmaya, kariyerden daha çok kendini ifade etmeye önem verirler" (Tuncer, 2016: 35).

\footnotetext{
30 21. yy ile iyiden iyiye belirginleşen ve çoğunlukla gelişmiş ülke coğrafyalarında kümelenen bilgi toplumları günümüzde teknoloji ile kurdukları uzun soluklu temaslar nedeni ile yeni alışkanlıklar kazanmıştır. Etkili zaman yönetiminden, sanal ortamlarda vakit geçirmeye kadar farklı alışkanlıkları bulunan bu toplumların bilgiye erişim yöntemleri de çeşitlilik göstermektedir.

${ }^{31}$ Müzelerin içinde bulundukları toplumların güncel özelliklerini analiz eden kurumlardır. Zira hedef kitleleri ve bu kitlelerin beklentilerini doğru tespit etmeleri amaçlarına ulaşmaları adına önem teşkil etmektedir.

32 İnsanlık tarihinde bireyden topluma dönüşme sürecinde çevre ile etkileşim her zaman mevcuttur. Bu etkileşim en başta insanın günlük yaşamına ve kültürel yapısına tesir etmiş, davranışlarının şekillenmesinde rol oynamıştır. Fakat zamanla gerek toplumsal yapı gerekse çevresel faktörler değişirken, (en başta iletişim konusuna) farklı dönemlerde doğup büyüyen insanlar arasında yeni tutumlar ortaya çıkmış, bu durum da kuşak farklılığı olarak adlandırılmıştır.
} 
Son olarak $Z$ kuşağına değinmek için $P$. Erten'in özünde farklı görüşlerden atıflara sahip tanımlamasından faydalanılabilir: "Dijital kuşak olan Z kuşağı, teknolojiye dayalı yaşam tarzları olan, sosyal medyayı üretken kullanan, yüksek teknoloji iletişimi çağında yaşayan, problemlerinin çözümünde teknolojiyi kullanabilecek yeteneğe sahip ve yüksek derecede bağlantıl olan bir kuşaktır. Bu nesil, genç, internetle büyüdü̈̆̈̈̈nden bilgiye hızh ulaşabilen, teknoloji meraklısı, formaliteye uymayan, çabuk öğrenen ve çeşitliliği kucaklayan bir nesildir. Özgüvenlidirler ve geleceklerini garanti altına almak isterler. Farklı düşünüp farklı bilgiyi işlemektedirler" (Erten, 2019: 191).

Referanslar, günümüz müzelerinin sergileme teknolojilerinin seçimi adına dikkate aldığı hedef kitle gruplarının özelliklerini en genel halleriyle betimlemektedir. Ancak sergileme teknolojisinin tercihi ve hedef kitle konusu sadece kuşaklar üzerinden ele alınamayacak genişlikte bir konudur. Öyle ki müzelerin hedef kitleleri dâhilinde ziyaretçilerin fiziksel durumlarını ilgilendiren gruplar da mevcuttur. Engelli bireylere işaret eden hedef kitle grupları bunlardan biridir. Dokunma ve işitme duyularını hedef alan sergileme teknolojileri bu gruplara kolaylıklar sunmak amacıyla da kullanılmaktadır. Ayrıca farklı yaş gruplarının fiziksel özelliklerinden de söz etmek gerekir. Örneğin $X$ kuşağı bireyleri artık birer yetişkin olmaları nedeniyle ortalama boy uzunluğu ve kilosuna erişmişken, $Z$ kuşağı henüz gelişim aşamasındadır. Bu kuşağın çocukluk veya ergenlik dönemindeki bireyleri hâlihazırda farklı vücut ölçülerine sahiptir. Tüm bu farklılıklar sergileme ve teknoloji tercihinde belirleyici detaylardır. ${ }^{33}$

\section{AVRUPA MÜZELERİNDE KULLANILAN SERGIILEME TEKNOLOJILERİ}

Hedef kitle gruplarına değindikten sonra saha araştırmalarında toplanan verilere ve bu verileri destekleyen görsellere yer verilebilir. Saha araştırmalarının ilk durağı Tablo 1'de belirtildiği gibi Fransa'nın Strazburg şehridir.

\subsection{Strazburg Tarih Müzesi (Strazburg / Fransa)}

Fransa'nın Strazburg şehri zengin tarihsel arka planı ile çok kültürlü bir kent olma özelliğindedir. Burada ziyaret edilen Strazburg Tarih Müzesi (Bkz. Resim 1), ülkenin İsviçre ve Almanya ile bağları bulunan Alsas ${ }^{34}$ bölgesinin tarihsel geçmişini ifade eden koleksiyonlara sahiptir.

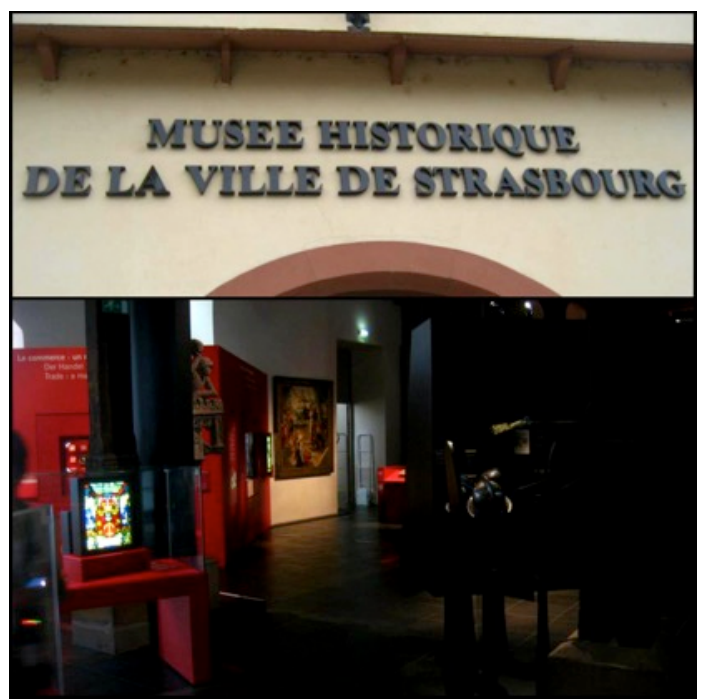

Resim 1. Strazburg Tarih Müzesi (Strazburg / Fransa). Dış ve iç mekândan kesitler. Kaynak: Burak BOYRAZ Arşivi, 2012.

\footnotetext{
${ }_{33}$ Altını çizmek gerekir ki; hedef kitle grupları zaman içinde farklılaşabilir, alt grupları oluşabilir.

$34 \mathrm{Bkz}$. Alsace.
} 
Ulusal tarih eğitimi açısından önemli bilgiler barındıran Strazburg Tarih Müzesi beklendiği gibi sergileme konusunda teknolojiden destek almıştır. Öne çıkan teknolojiler $Y$ ve $Z$ kuşaklarının kolaylıkla benimseyeceği türdendir. Bunları görme, işitme ve dokunma duyularına hitap eden; sesli rehberler, kiosklar ${ }^{35}$, yüksek çözünürlüklü dijital ekranlar ve holografi36 teknolojileri olarak sıralamak mümkündür.

Sesli rehberler eskiden olduğu gibi kablolu kulaklıklardan faydalanmaktadır. Görsel ve işitsel donanımları oldukça güncel olup, yer yer birden fazla duyuyu hareketlendiren kiosklar ve yüksek çözünürlüklü dijital ekranlar ise müze için hazırlanan tematik (ve çok dilli) özgün yazılımlara sahiptir (Bkz. Resim 2 ve 3). En başta bölge tarihine yönelik bilgiler vermek ve belirli nesneleri işlevleri bağlamında yorumlamak için kullanılan bu teknolojiler projeksiyonlar ile desteklenmiştir.

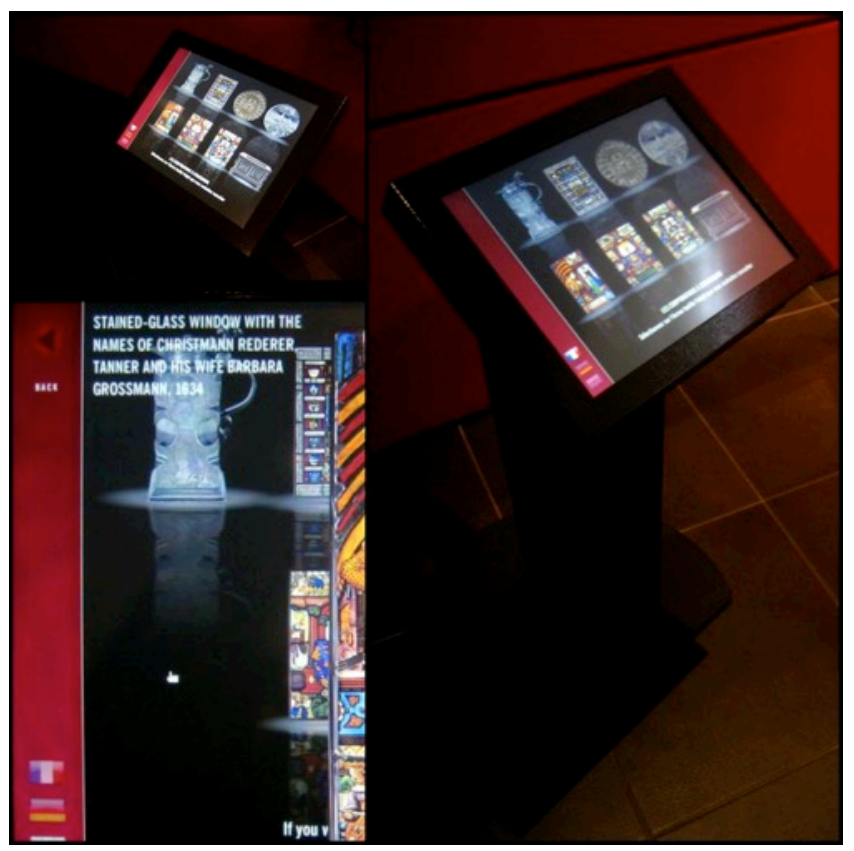

Resim 2. Strazburg Tarih Müzesi (Strazburg / Fransa). Sergi salonlarında konumlandırılan kiosklardan ve sahip oldukları ara yüzlerden örnekler. Kaynak: Burak BOYRAZ Arşivi, 2012.

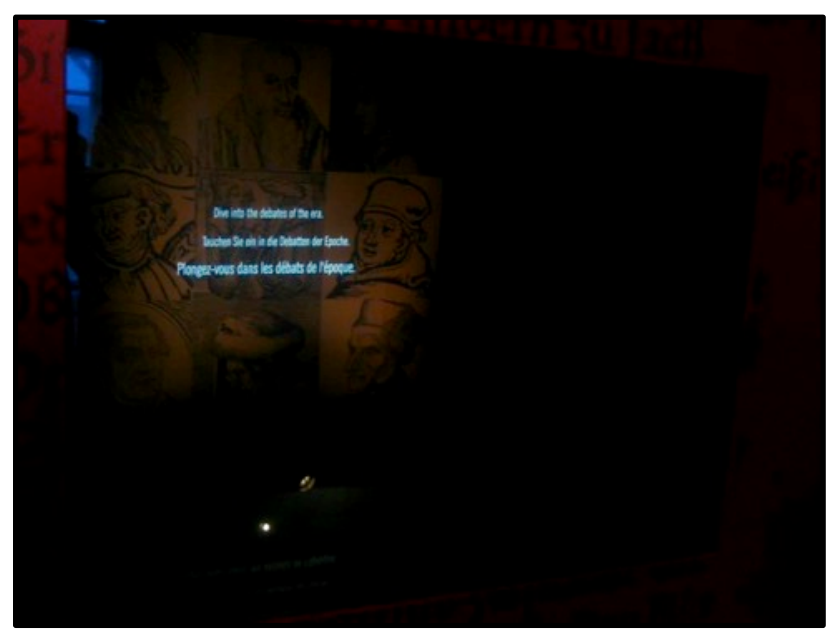

Resim 3. Strazburg Tarih Müzesi (Strazburg / Fransa). Sergi salonlarında duvara gömülü biçimde konumlandırılan yüksek çözünürlüklü dijital ekranlardan bir örnek. Kaynak: Burak BOYRAZ Arşivi, 2012.

\footnotetext{
${ }^{35}$ Elektronik bilgi terminalleri

${ }^{36}$ Holografi teknolojisi, lazer ışınlarının yardımıyla oluşturulan üç boyutlu görüntülere dayanan teknolojidir.
} 
Projeksiyonların sergilemedeki misyonu genel bilgi akışı ile ilişkili olan (tarihi şahısların figürleri gibi) yan görseller sunmaktır. Bu görsellerin sunumu için sergi salonlarındaki duvarları kullanmak yerine merkezi bir noktada tavana yerleştirilen üç boyutlu projeksiyon perdelerinden yararlanılmıştır (Bkz. Resim 4).

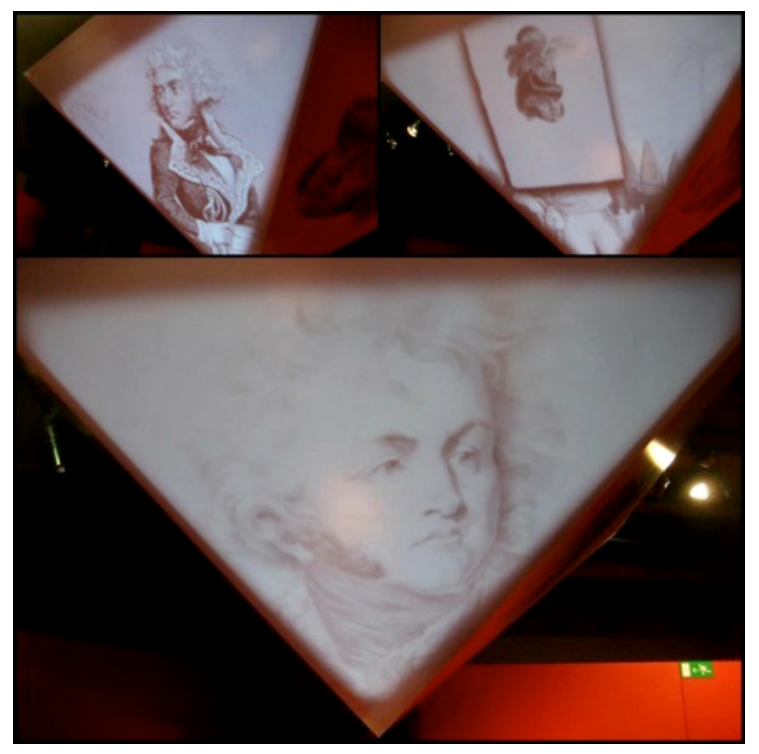

Resim 4. Strazburg Tarih Müzesi (Strazburg / Fransa). Sergi salonlarında tavana konumlandırılan üç boyutlu projeksiyon perdesi. Kaynak: Burak BOYRAZ Arşivi, 2012.

Holografi teknolojisinin müzedeki kullanım alanı ise şehrin yüzyıllar içindeki değişimini ve farklılaşan gündelik yaşamını betimlemektir. Ayrıca savaşları, ayaklanmaları ve bunlarla ilgili toplumsal girişimleri ifade etmek için de bu teknolojiden faydalanılmıştır.

İşlevsel açıdan baktığımızda; Holografi teknolojisi kentin küçük ölçekli bir maketinin hemen üzerine yerleştirilmiştir. Bu teknoloji vasıtası ile imgesel bir karakterin anlatımı eşliğinde "ziyaretçinin seçtiği"37 olaylar hakkında hareketli bilgiler verilmektedir (Bkz. Resim 5). Çatışmalara ve askeri manevralara dair animasyonlar maket üzerinde vuku buldukları; kasabalar, sokaklar, caddeler ve açık araziler üzerinde canlandırılmaktadır.

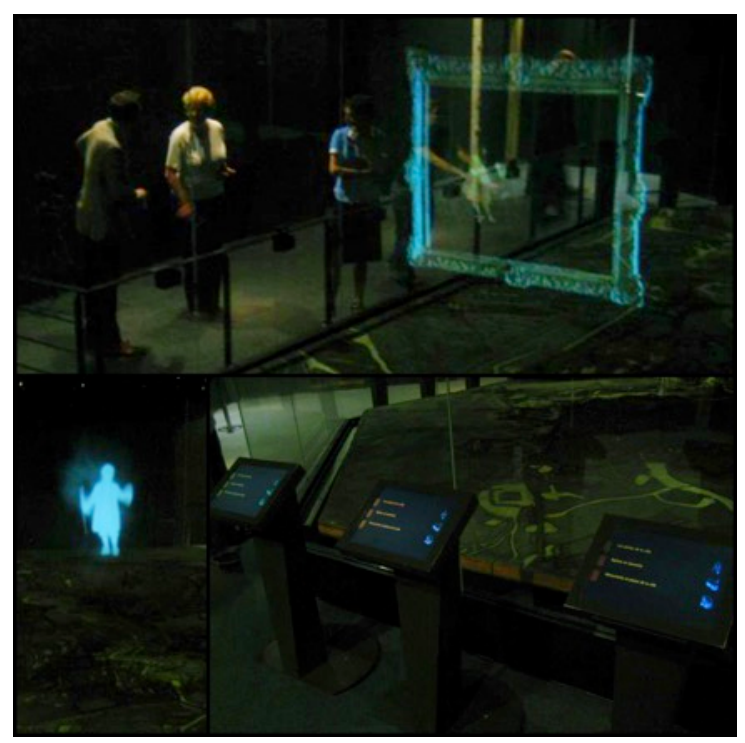

Resim 5. Strazburg Tarih Müzesi (Strazburg / Fransa). Müzede kullanılan ve şehrin küçük ölçekli maketi üzerine konumlandırılan holografi sistemi. Kaynak: Burak BOYRAZ Arşivi, 2012.

\footnotetext{
${ }^{37}$ İlgili seçimler dokunmatik ekranlara sahip kontrol panelleri üzerinden yapılmaktadır.
} 
Müzede sergilemeleri adına teknolojiden dolaylı yoldan destek alan koleksiyonlar da mevcuttur. Örneğin yerel madeni paraların bulunduğu nümizmatik koleksiyonuna ait bilgiler (tarihsel bağlantıları nedeniyle) diğer salonlardaki kiosklarda "seçmeli bilgi" olarak sunulmuştur. Bu çerçevede nümizmatik koleksiyonu hakkındaki bilgilerin aktarımında (kendi alanları içinde) sadece pano ve etiketlerden yararlanılmış, başka herhangi bir teknoloji kullanılmamıştır. Koleksiyonun sergilemesi kapsamında dikkat çeken araçlar, vitrinlere ziyaretçilerin koleksiyon parçalarının detaylarını incelemesi için monte edilen büyüteçlerdir (Bkz. Resim 6).

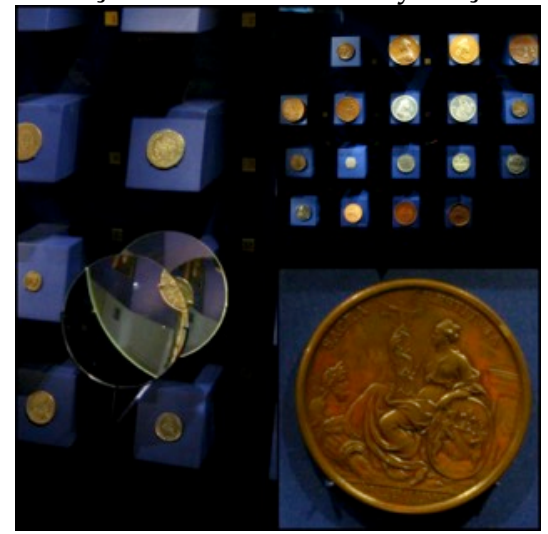

Resim 6. Strazburg Tarih Müzesi (Strazburg / Fransa). Nümizmatik koleksiyonundan kesitler. Kullanılan büyüteçlerden biri solda görülebilir. Kaynak: Burak BOYRAZ Arşivi, 2012.

\subsection{Strbistan Tarih Müzesi ve Nikola Tesla Müzesi (Belgrad / Sırbistan)}

Sırbistan Tarih Müzesi adından da anlaşılabileceği gibi Sırp halkının geçmişine yönelik nesneleri barındıran bir müzedir. Başkent Belgrad'da yer alan bu müzede çoğunlukla 20.yy'a ait olan el yazmaları, askeri ekipmanlar, sanat eserleri ve etnografik nesneler bulunmaktadır. Müzede koleksiyonların sergilenmesi için üç duyuya da hitap teknolojiler tercih edilmiştir. Bunlar genel bir gruplama ile; sesli rehberler, projeksiyonlar ve kiosklardır (Bkz. Resim 7).

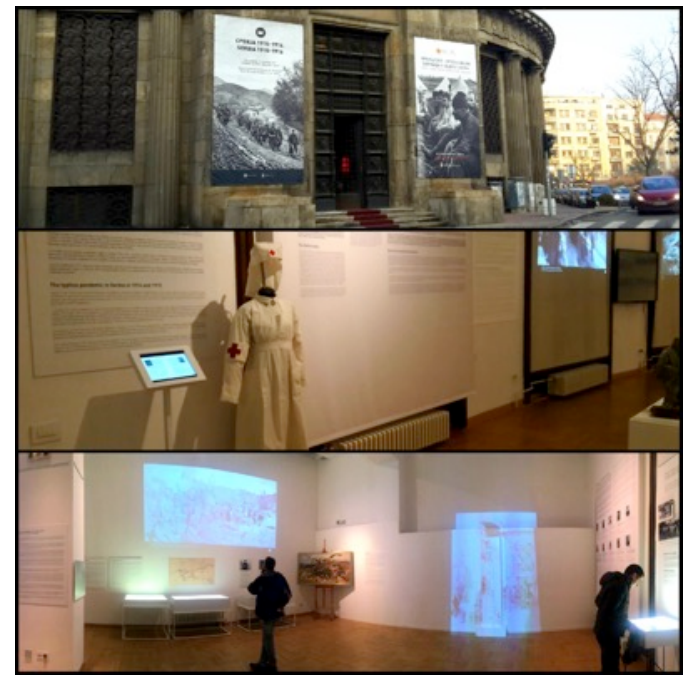

Resim 7. Sırbistan Tarih Müzesi (Belgrad / Sırbistan). Dış cephe ve iç kısımlardan kesitler. Kaynak: Burak BOYRAZ Arşivi, 2017.

Sırbistan Tarih Müzesi'ndeki sesli rehberler bilgiyi numaralandırma sistemi üzerinden aktarırken, projeksiyonlar nesnelere dair fotoğraf ve grafikleri sergi salonlarına yansitmak amaciyla kullanılmıştır (Bkz. Resim 7, en alt kesit). Kiosklar ise ziyaretçilere koleksiyon içeriklerine göre 
bilgiler sunmaktadır. Bu bilgiler (farklı dillerdeki anlatımları da bulunan); siyasi tarih odaklı sayısal dökümler, muharebeler ve biyografiler gibi konuları kapsamaktadır (Bkz. Resim 8).

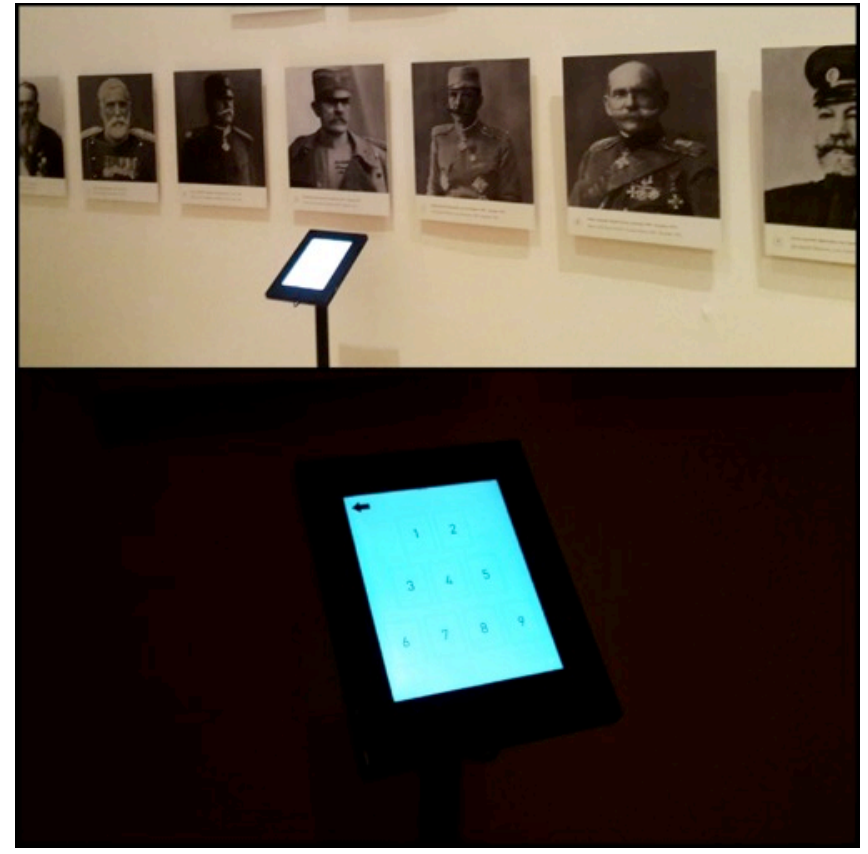

Resim 8. Sırbistan Tarih Müzesi (Belgrad / Sırbistan). Müzede kullanılan ve askeri liderlerin kısa biyografileri ile zaferlerini aktaran kiosklardan kesitler. Kaynak: Burak BOYRAZ Arşivi, 2017.

Sergileme teknolojilerinin kullanımı adına daha geniş kapsamlı bir yaklaşıma sahip olan Nikola Tesla Müzesi'nden bahsedersek, müze bilim tarihinin en tanınmış mucitlerinden biri olan Sırp kökenli Nikola Tesla'nın (1856-1943) anısı için kurulmuştur (Bkz. Resim 9).

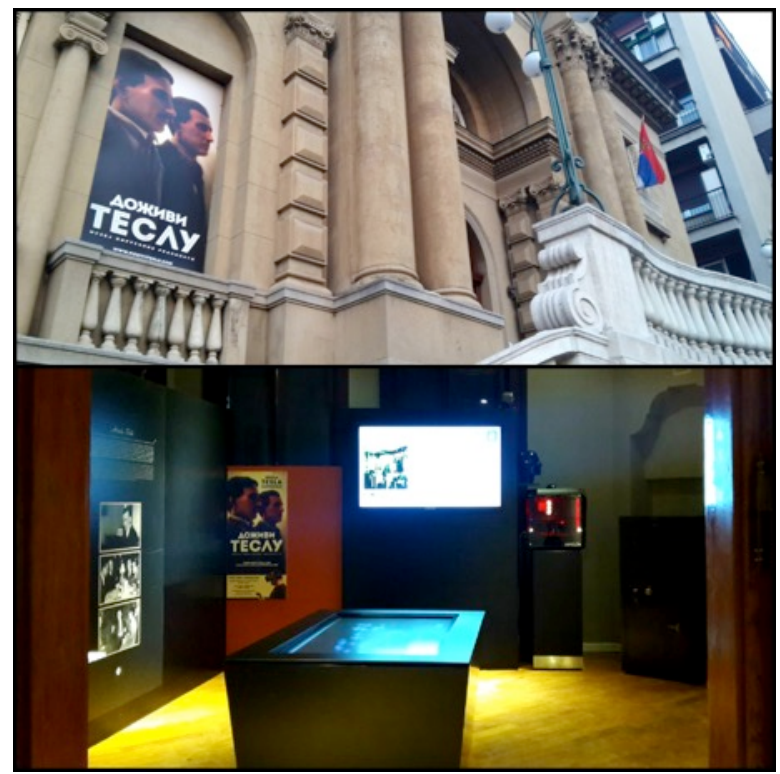

Resim 9. Nikola Tesla Müzesi (Belgrad / Sırbistan). Dış cephe ve iç mekândan kesitler. Kaynak: Burak BOYRAZ Arşivi, 2017.

Müzede N. Tesla'nın kişisel eşyaları mevcuttur. Fakat kurumun ayırt edici özelliği; ziyaretçilere enerji kavramı ve $N$. Tesla'nın buluşlarına yönelik bilgileri etkileşimsel araçlar eşliğinde deneyimleyerek öğrenme fırsatı sunmasıdır. Bu anlamda sergi salonlarında en başta fen bilimlerini ilgilendiren ve genellikle elektrik enerjisine yönelik çalışma prensiplerini gösteren 
replika cihazlar yer almaktadır (Bkz. Bobinler vb.). Müze sözünü ettiğimiz deneyimleyerek öğrenme yaklaşımı çerçevesinde düzenlediği eğitim etkinliklerinde bu replikalardan destek almaktadır (Bkz. Resim 10). İlgili teknolojiler de bu replikaların alt metinlerini anlaşılır kılacak biçimde kurgulanmış, farklı duyuları hedef alan bir sergileme politikası izlenmiştir.

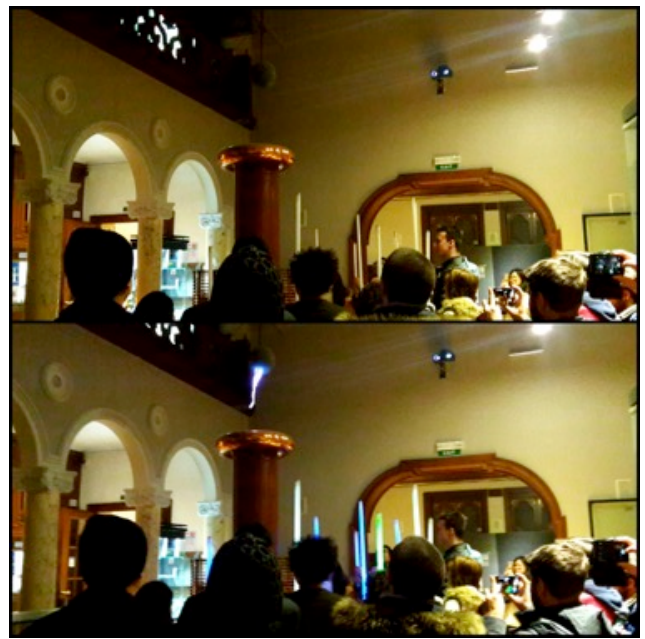

Resim 10. Nikola Tesla Müzesi (Belgrad / Surbistan). Müzedeki eğitim etkinliklerinden kesitler. Kablosuz enerji aktarımının işlendiği bu etkinlikte ziyaretçiler kendilerine müze tarafından verilen lambaların kaynaktan gelen enerji ile nasıl aydınlandı̆̆ını gözlemlemektedir. Görselde üstteki kesitte; kaynak kapalı durumdayken lambalar sönük haldedir. Alttaki kesitte ise; kaynağın harekete geçmesi ile lambalar da aydınlatır duruma geçmiştir. (Bkz. Tesla Elektrik Bobini).

Kaynak: Burak BOYRAZ Arşivi, 2017.

Söz konusu teknolojiler arasında; kiosklar, yüksek çözünürlüklü dijital ekranlar, üç boyutlu yüzeyler üzerinde kullanılan projeksiyonlar ve holografi cihazları öne çıkmaktadır.

Müzede yer alan ve $N$. Tesla'nın ürettiği enerji kaynaklarının izlediği protokolleri açıklamak amacıyla kullanılan bu teknolojiler arasında; kiosklar ve yüksek çözünürlüklü dijital ekranlar ziyaretçilere çoğunlukla terminolojik ve kavramsal bilgileri aktarmaktadır (Bkz. Resim 11).

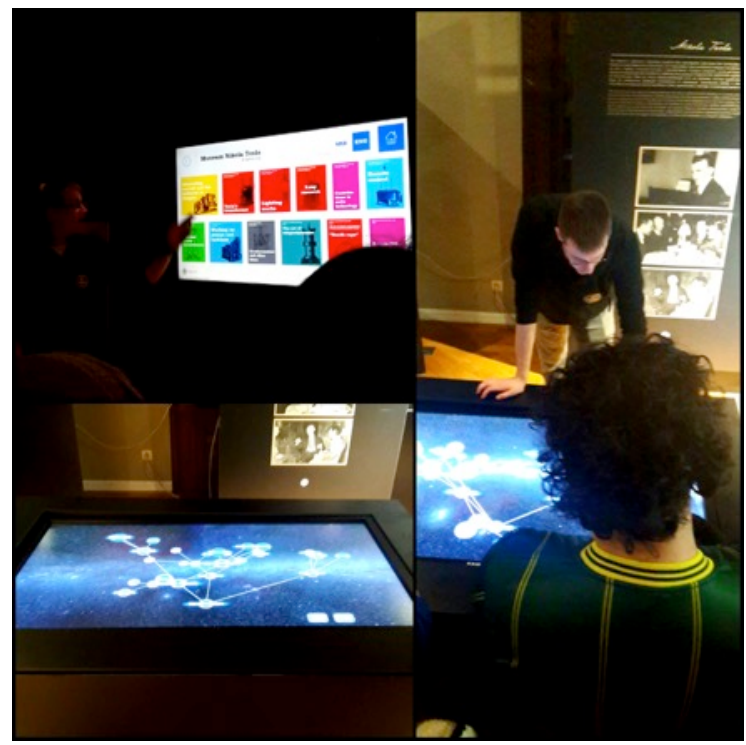

Resim 11. Nikola Tesla Müzesi (Belgrad / Sırbistan). Müzede kullanılan kiosklar ve yüksek çözünürlüklü dijital ekranlar. Her iki teknolojide de infografiklerden yararlanılmıştır. Kaynak: Burak BOYRAZ Arşivi, 2017.

Üç boyutlu yüzeyler üzerine yansitılan projeksiyonlardaki temel amaç ise doğa dostu enerji kaynaklarını anlatmak ve sürdürülebilir enerji kavramının açıklanmasına yardım etmektir (Bkz. 
Resim 12). Benzer bilgiler holografi cihazları üzerinden de verilmektedir. Fakat holografi cihazlarında ağırlıklı olarak enerji adına kullanılan daha eski yöntemler tasvir edilmektedir. (Bkz. Resim 13).

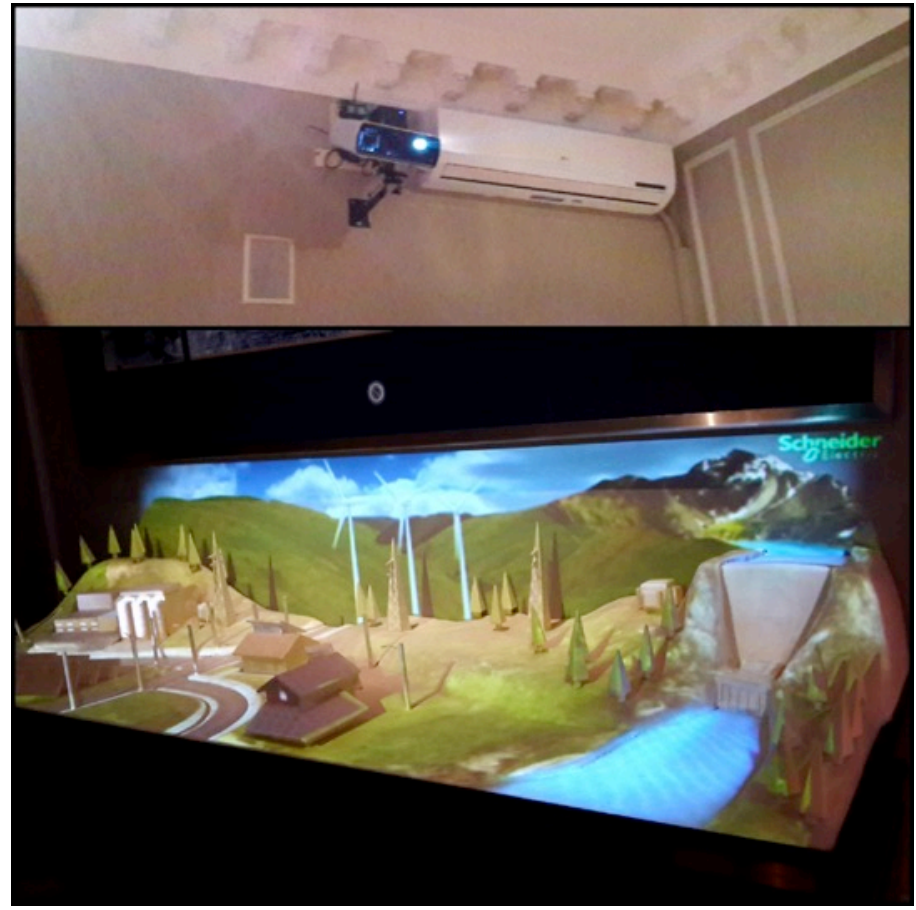

Resim 12. Nikola Tesla Müzesi (Belgrad / Sırbistan). Müzede kullanılan projeksiyon teknolojisinden kesitler. Projeksiyon görüntüleri beyaz köpükten yapılmış olan üç boyutlu bir şehir maketi üzerine yansıtılmaktadır. Makete hareketlilik kazandıran bu teknoloji ile betimlenen konu "enerjidir". Kaynak: Burak BOYRAZ Arşivi, 2017.

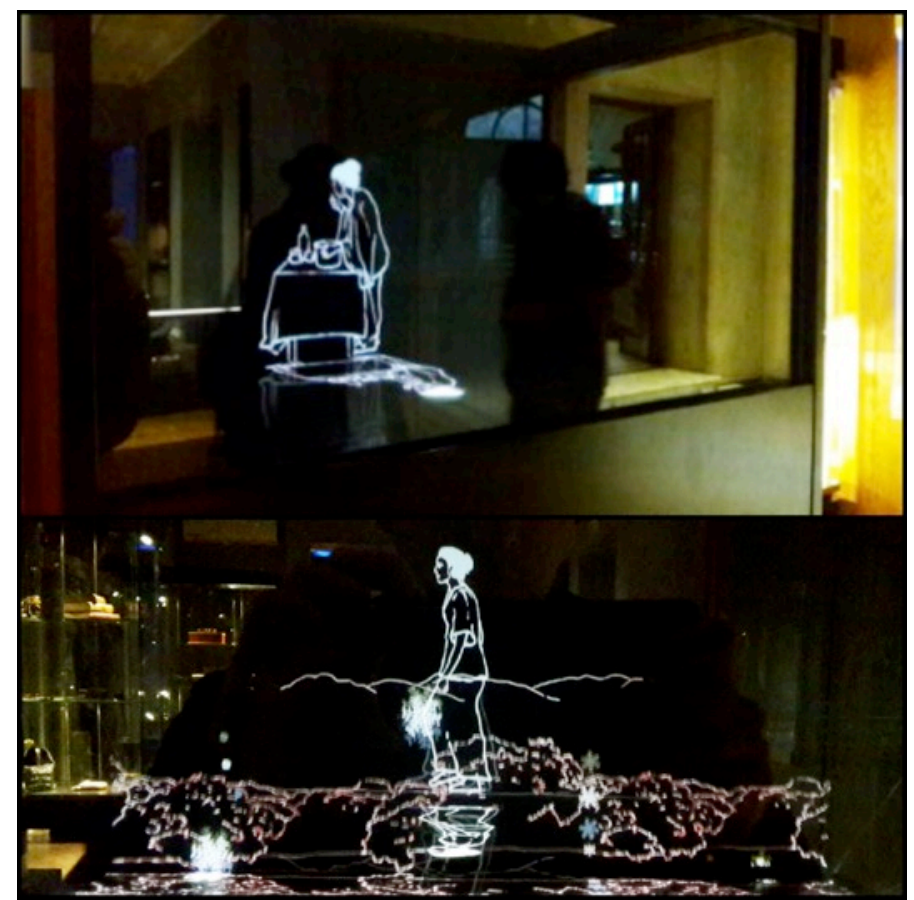

Resim 13. Nikola Tesla Müzesi (Belgrad / Sırbistan). Müzede kullanılan holografi teknolojisinden kesitler. (Buhar enerjisi konusunun holografi ile anlatımıdır). Kaynak: Burak BOYRAZ Arşivi, 2017. 


\subsection{Akropolis Müzesi ve Kiklad Sanat Müzesi (Atina / Yunanistan)}

Yunanistan'ın başkenti Atina ülkenin kalabalık nüfuslu şehirlerindendir. Eski Yunan uygarlıklarının kalıntılarına ev sahipliği yapan bu şehrin en bilindik müzelerinden biri ise Akropolis Müzesi'dir (Bkz. Resim 14). Müzenin koleksiyonları kentin Akropolis Tepesinde gerçekleştirilen kazılarda edinilen arkeolojik nesne gruplarından oluşmaktadır.

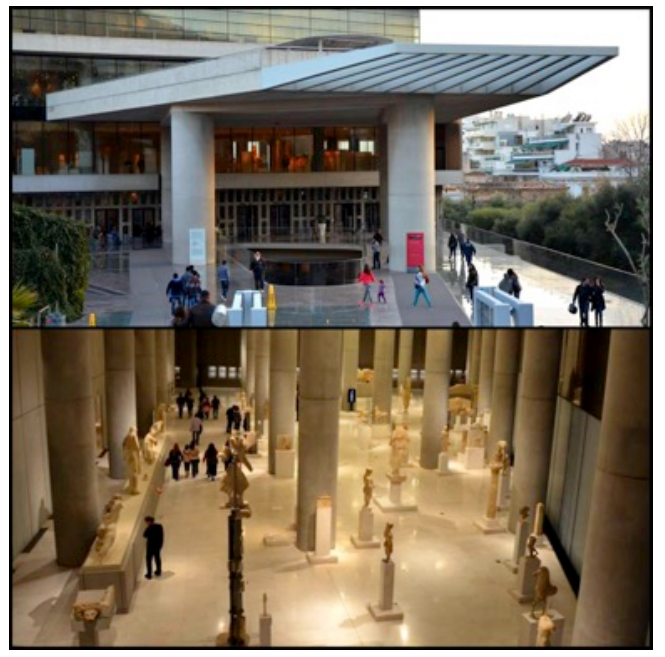

Resim 14. Akropolis Müzesi (Atina / Yunanistan). Diş cephe ve iç mekândan kesitler. Kaynak: Burak BOYRAZ Arşivi, 2017.

Akropolis Müzesi'nin kullandığı belli başlı sergileme teknolojileri sesli rehberler ve yüksek çözünürlüklü dijital ekranlardır. (Ziyaretçilere arkeolojik bilgiler sunmak için kullanılan bu cihazlara sayıca çok az olan kiosklar eşlik etmiştir). Sesli rehberler, numaralandırma sistemi ile nesnelerin hangi zaman diliminde hangi kazıda bulunduğuna dair bilgiler sunmaktadır. Yüksek çözünürlüklü dijital ekranlar da benzer bir işlev görmekteyken, içerikleri ağırlıklı olarak Akropolis kazılarını anlatan belgeseller ve seçili nesnelerin önemini vurgulayan kısa anlatımlardan oluşmaktadır. Diğer müzelerden farklı olarak Akropolis Müzesi'ndeki yüksek çözünürlüklü ekranlarda birden fazla ekran ayn görüntüyü paylaşımlı biçimde aktaracak şekilde kombine edilmiştir (Bkz. Resim 15).

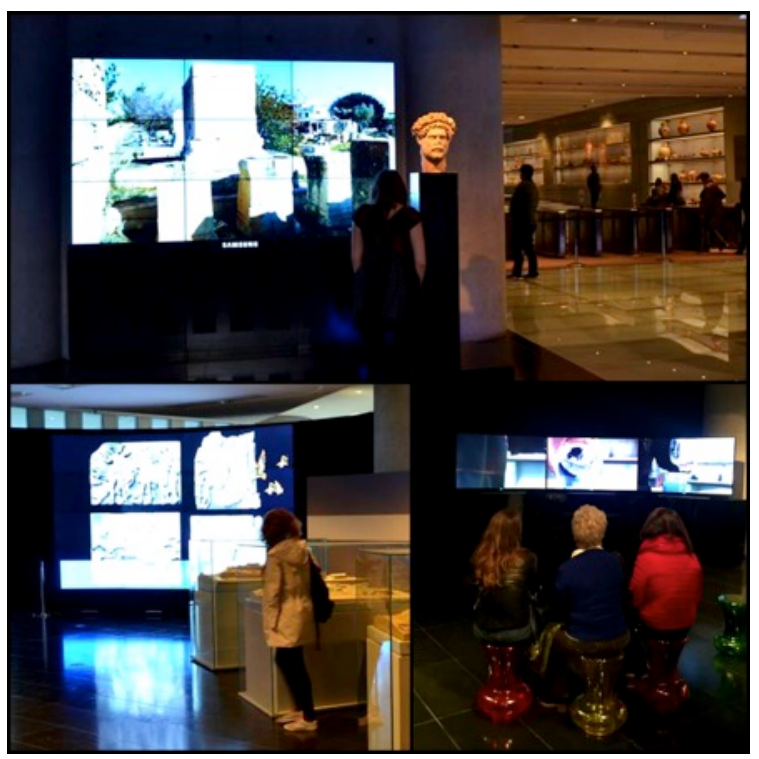

Resim 15. Akropolis Müzesi (Atina / Yunanistan). Müzedeki yüksek çözünürlüklü dijital ekranlardan kesitler. Kaynak: Burak BOYRAZ Arşivi, 2017. 
Atina'da ziyaret ettiğimiz bir diğer müze ise Kiklad Sanat Müzesi'dir (Bkz. Resim 16). Kökleri çok eskilere dayanan Kiklad Uygarlığının kalıntılarına ev sahipliği yapan bu müzede kullanılan teknolojik araçlar ağırlıklı olarak yine sesli rehberler ve kiosklardır. Sesli rehberler Akropolis Müzesi'ndekiler ile ayn işlevi görmektedir. Ancak Kiklad Sanat Müzesi'nde Akropolis Müzesi'nin aksine kiosklar neredeyse tüm sergileme alanlarına dağılmıştır. İnfografik anlatımlı bilgi panoları ile birbirlerini destekleyecek biçimde konumlandırılan kiosklarda Kiklad Uygarlığının tarihi ve mevcut koleksiyon nesnelerinin hangi amaçlar için üretildiği gibi genel bilgiler yer almaktadır (Bkz. Resim 17 ve 18).

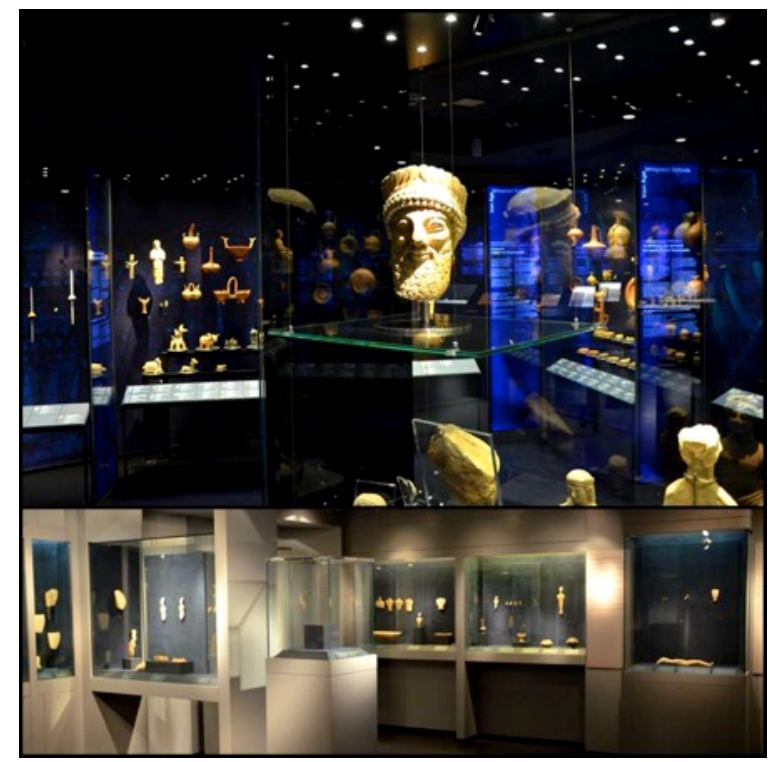

Resim 16. Kiklad Sanat Müzesi (Atina / Yunanistan). İç kısımlardan kesitler. Kaynak: Burak BOYRAZ Arşivi, 2017.

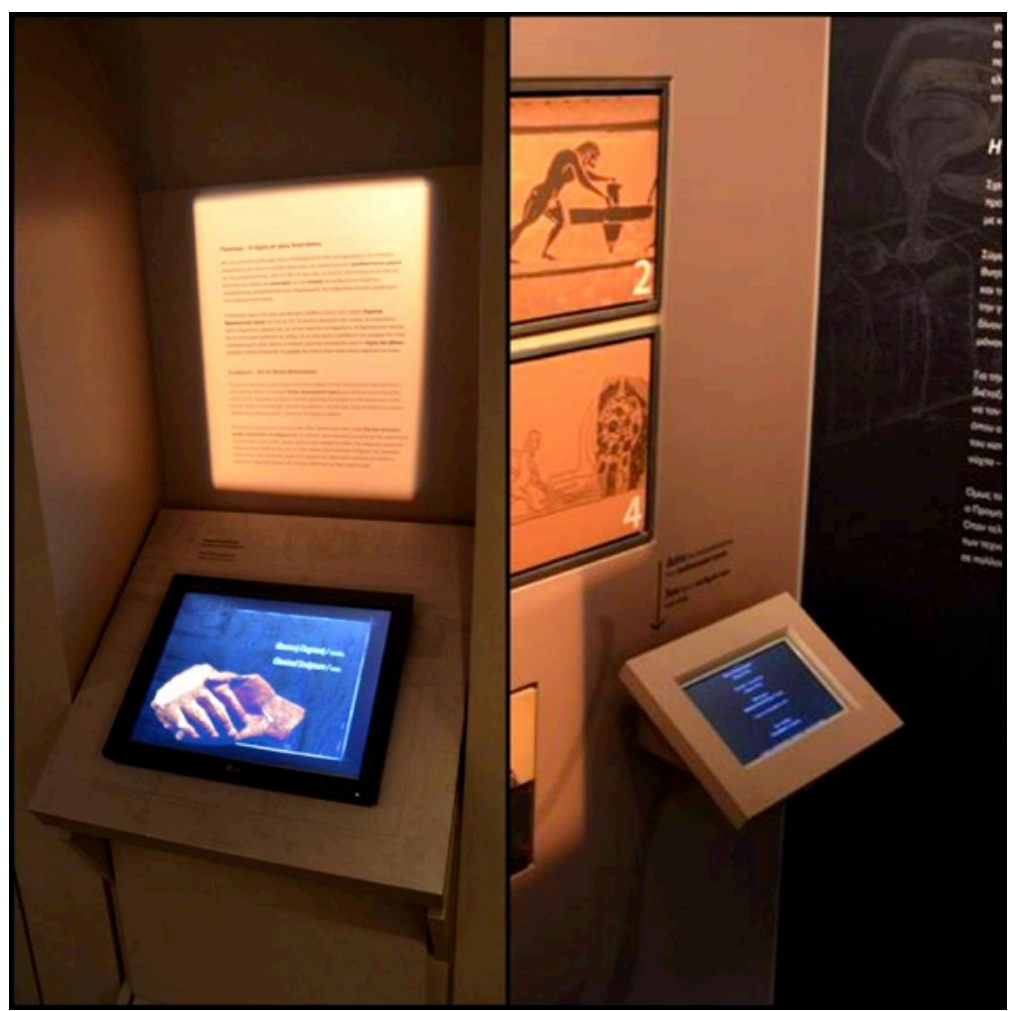

Resim 17. Kiklad Sanat Müzesi (Atina / Yunanistan). Müzede sergilemelerde kullanılan kiosklardan kesitler 1. Kaynak: Burak BOYRAZ Arşivi, 2017. 


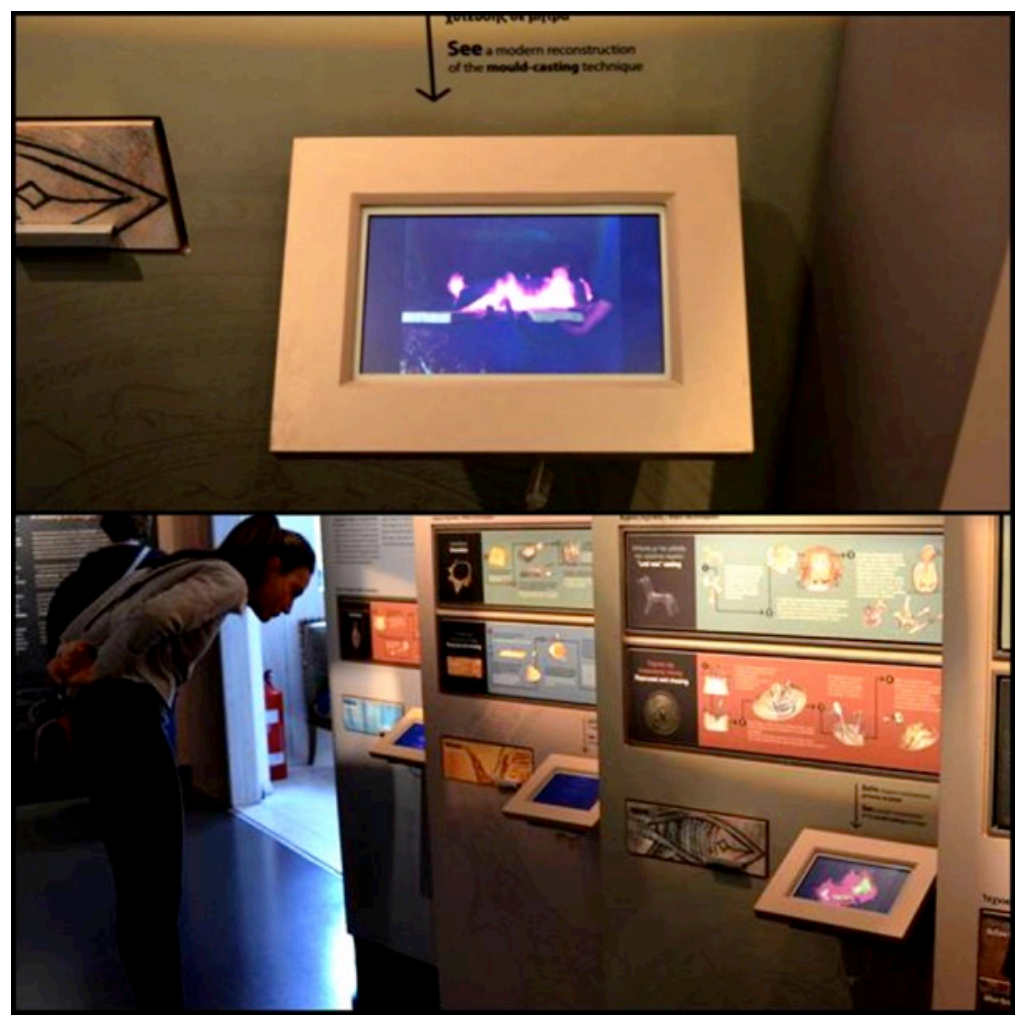

Resim 18. Kiklad Sanat Müzesi (Atina / Yunanistan). Müzede sergilemelerde kullanılan kiosklardan kesitler 2. Kaynak: Burak BOYRAZ Arşivi, 2017.

\subsection{Zagreb Çăğdaş Sanatlar Müzesi ve Zagreb Tarih Müzesi (Zagreb / Hirvatistan)}

Coğrafi olarak Orta Avrupa ve Balkanlara temas eden Hırvatistan Adriyatik Denizi'ne kıyıları olan ve uluslararası kültür - sanat girişimlerine sıklıkla ev sahipliği yapan bir ülkedir. Saha araştırmalarında ülkenin başkenti Zagreb şehri ziyaret edilmiş, sergileme teknolojilerine yönelik veriler; Zagreb Çağdaş Sanatlar Müzesi ve Zagreb Tarih Müzesi'nde toplanmıştır.

Zagreb Çă̆daş Sanatlar Müzesi (ağırlıklı olarak) 20.yy sanat eserlerinden oluşan bir koleksiyona sahiptir. Bu koleksiyon yerel sanatçıların eserlerini barındırdığı gibi pek çok uluslararası sanatçının yapıtına da ev sahipliği yapmaktadır (Bkz. Resim 19).

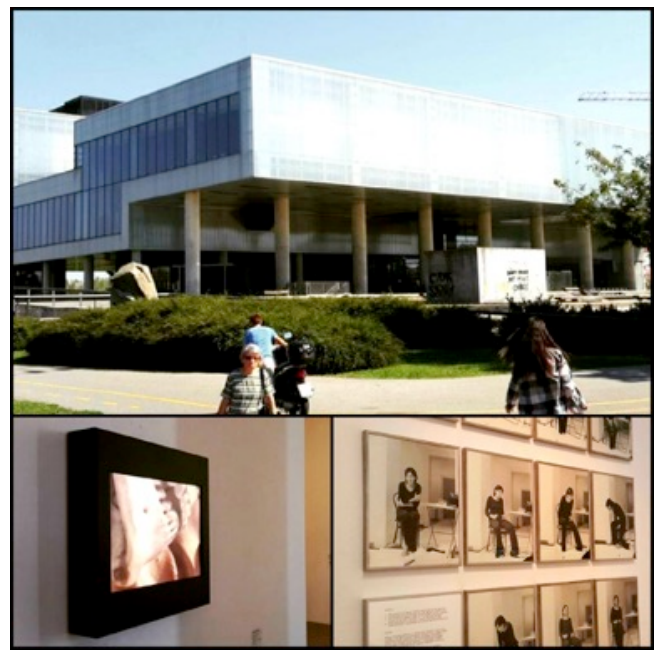

Resim 19. Zagreb Çă̆gaş Sanatlar Müzesi (Zagreb / Hırvatistan). Dış cephe ve iç kısımlardan kesitler. Kaynak: Burak BOYRAZ Arşivi, 2017. 
Söz konusu koleksiyonda 20.yy'ın son çeyreğinde öne çıkan video sanatı akımına dâhil edilebilecek eserler de bulunmaktadır. Bu eserlerin sergilemelerinde üretildikleri dönemin teknolojileri dikkate alınmıştır. Örneğin video sanatının ilk zamanları ile 21.yy'ın başlarındaki üretimler gerek görüntü kalitesi gerekse ses anlamında farklı nüanslara sahiptir. Dolayısıyla yeni yapıtlar kulaklıklara sahip yüksek çözünürlüklü dijital ekranlarda sunulurken, eski yapıtlar bağlamlarından koparılmamak için kutu tipi televizyonlarda takdim edilmiştir (Bkz. Resim 20).

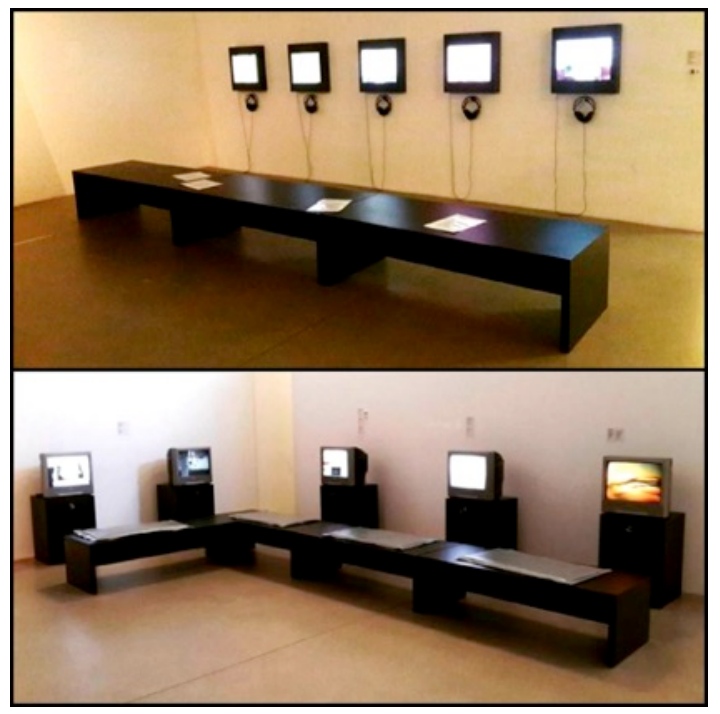

Resim 20. Zagreb Çă̆gaş Sanatlar Müzesi (Zagreb / Hırvatistan). Video sanatı akımına dâhil olan eserlerin sergilemelerinden kesitler. Üstte yeni yapıtlar için kullanılan yüksek çözünürlüklü dijital ekranlar. Altta kutu tipi televizyonlar. Kaynak: Burak BOYRAZ Arşivi, 2017.

Mevzu bahis dijital ekranlar sadece video sanatına temas edecek şekilde kullanılmamıştır. Müzede sanat tarihi konularına, ilgili biyografilere ve sanat yapıtlarının üretim / icra süreçlerine yönelik bilgi akışını sağlamak adına da yüksek çözünürlüklü dijital ekranlardan faydalanılmıştır. Örnekle Marina Abramović'in (1946) performanslarında kullandığı nesneler, sanatçının hazırlık ve icra süreçlerine dair belgesel görüntüleri ile kompoze edilmiştir (Bkz. Resim 21).

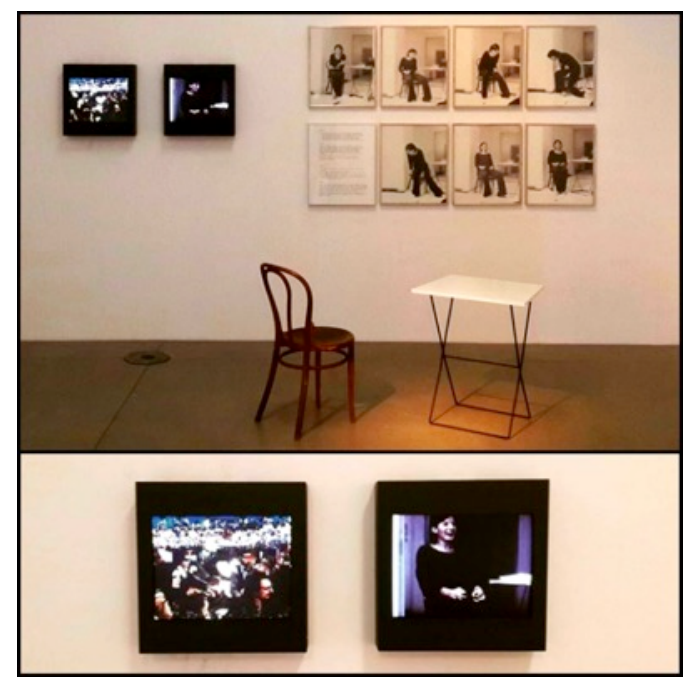

Resim 21. Zagreb Çă̆daş Sanatlar Müzesi (Zagreb / Hırvatistan). Marina Abramović'in (1946) performanslarında kullandı ̆̆ı nesnelerin sergilemesinden kesitler. Görsel üzerinden ilgili belgeselleri içeren yüksek çözünürlüklü dijital ekranlar görülebilir. Kaynak: Burak BOYRAZ Arşivi, 2017. 
Dijital ekranlar müzedeki eğitim alanlarında da kullanılmıştır. Farklı hedef kitlelere yönelik sanal sanat uygulamalarını barındıran bu ekranlar ziyaretçileri deneyim kazanmaya / bilgi edinmeye teşvik etmek amacıyla açık (duvarsız) bir ortamda konumlandırılmıştır (Bkz. Resim 22).

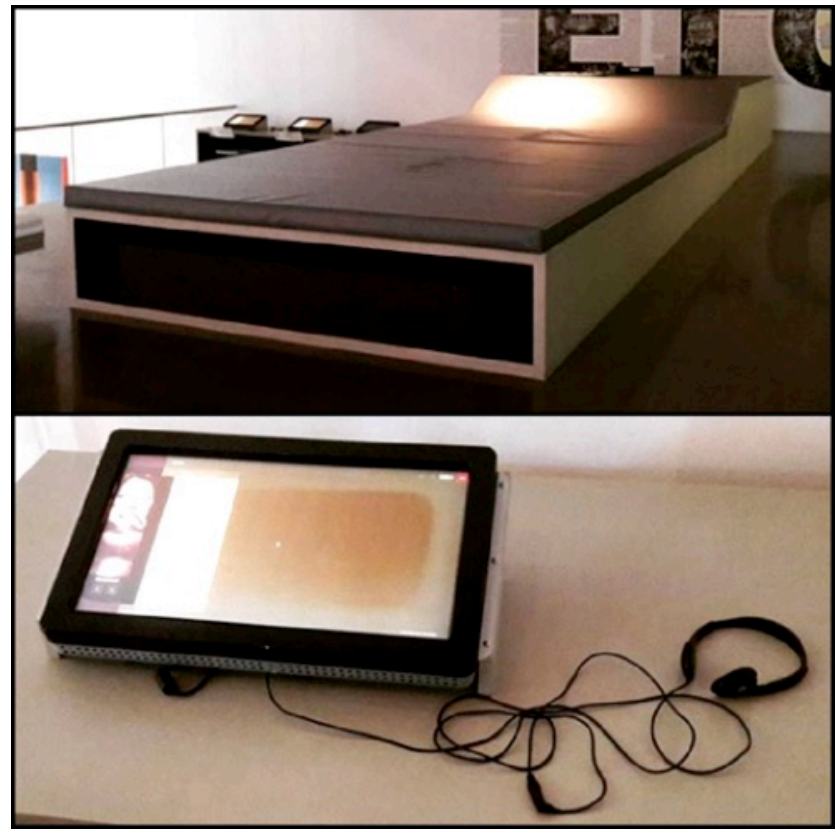

Resim 22. Zagreb Çağdaş Sanatlar Müzesi (Zagreb / Hırvatistan). Müzede dijital ekranların kullanıldığı alan (aynı zamanda eğitim alanıdır). Kaynak: Burak BOYRAZ Arşivi, 2017.

Zagreb Çağdaş Sanatlar Müzesi en başta koleksiyon içeriği nedeniyle görüntüleme teknolojilerinden yararlanmıştır. Ancak müzede kullanılan teknolojiler bunlarla sınırlı değildir. Sesli rehberler hemen hemen tüm sergi alanlarında işlevseldir. Sesli rehberler konusunda izlenen politika ilgili biyografilere ve sanat yapıtlarının üretim / icra süreçlerinin ifadesine yöneliktir ( $B k z$. Resim 23).

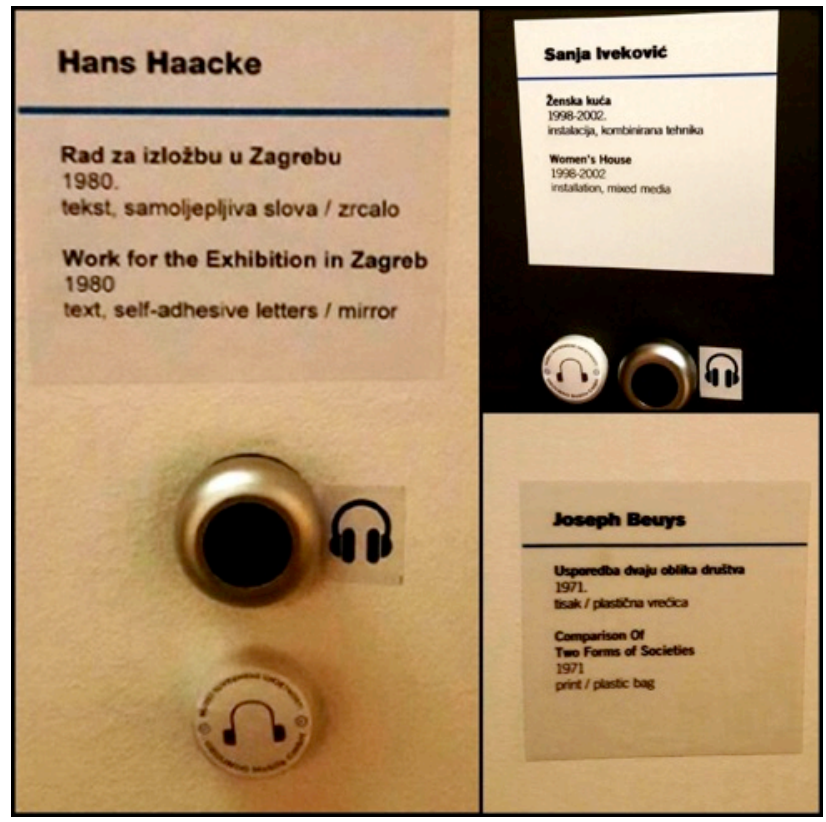

Resim 23. Zagreb Çağdaş Sanatlar Müzesi (Zagreb / Hırvatistan). Sesli rehberlere işaret eden etiketler. Kaynak: Burak BOYRAZ Arşivi, 2017.

Ziyaret ettiğimiz bir diğer müze olan Zagreb Tarih Müzesi'nde de benzer yaklaşımlar mevcuttur. 
Zagreb Tarih Müzesi şehir halkının farklı dönemlerinde kullandığı günlük yaşam nesnelerini kapsayan ve yakın geçmişinde tanıklık ettiği askeri olaylara göndermeler yapan bir koleksiyonu barındırmaktadır (Bkz. Resim 24). Bu anlamda söz konusu nesnelerin arka planları ve ülkede yaşanan olaylara dair belgeseller ziyaretçilere yüksek çözünürlüklü dijital ekranlar ile sunulmuştur (Bkz. Resim 24, sol alt kesit). İlgili ekranlar aynı zamanda müzedeki etkileşimsel uygulamalar ile koordine edilmiştir. Örneğin çatışma / muharebe dönemlerinde Zagreb’de zarar gören mekânların "öncesi ve sonrası" durumlarını betimleyen etkileşimsel uygulamadaki görsellere, yüksek çözünürlüklü dijital ekranlarda da yer verilmiştir (Bkz. Resim 25).

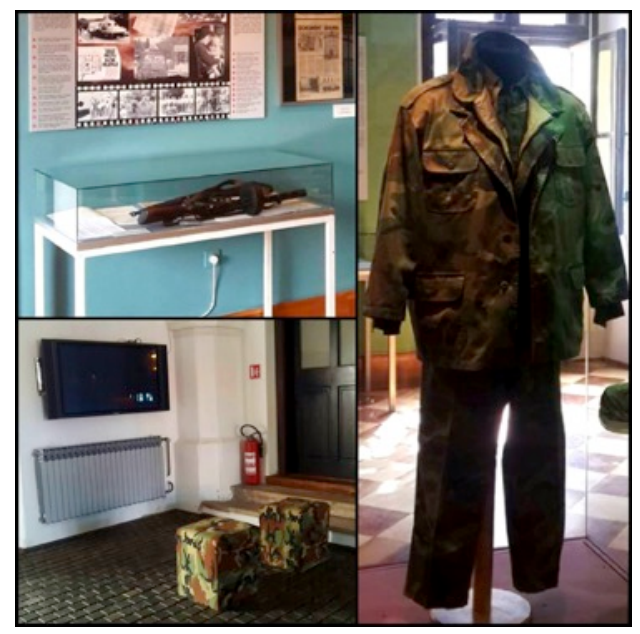

Resim 24. Zagreb Tarih Müzesi (Zagreb / Hırvatistan). Müzedeki yüksek çözünürlüklü dijital ekranlarından biri (sol alt kesit) ve müzenin koleksiyon nesnelerinden kesitler. Kaynak: Burak BOYRAZ Arşivi, 2017.

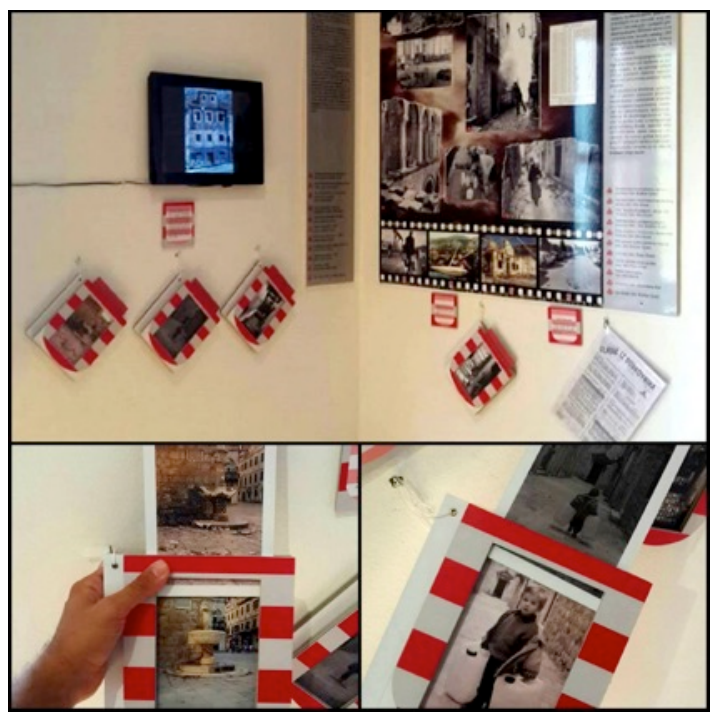

Resim 25. Zagreb Tarih Müzesi (Zagreb / Hırvatistan). Müzede sergi salonlarında konumlandırılan ve muharebe dönemlerinde şehirde zarar gören mekânların "muharebe öncesi ve sonrası" durumlarını betimleyen etkileşimsel uygulama. (Maket malzemelerinden yapılmıştır). Kaynak: Burak BOYRAZ Arşivi, 2017.

\subsection{Aşă̆ı Saksonya Eyalet Müzesi (Hannover / Almanya)}

Son müzemiz Aşağı Saksonya Eyalet Müzesi ülkenin fuar kenti olarak bilinen (ve Aşağı Saksonya eyaletinin de başkenti olan) Hannover şehrinin en geniş koleksiyonlu müzelerinden biridir (Bkz. Resim 26). Geçmişi 19.yy'a kadar dayanan bu müze günümüzde mevcut koleksiyonlarını beş ana 
başlık altında gruplandırmıştır. Bunlar: Sanat Koleksiyonu, Doğa Tarihi Koleksiyonu³, Arkeoloji Koleksiyonu, Etnoloji Koleksiyonu ve Nümismatik Koleksiyonu'dur. ${ }^{39}$

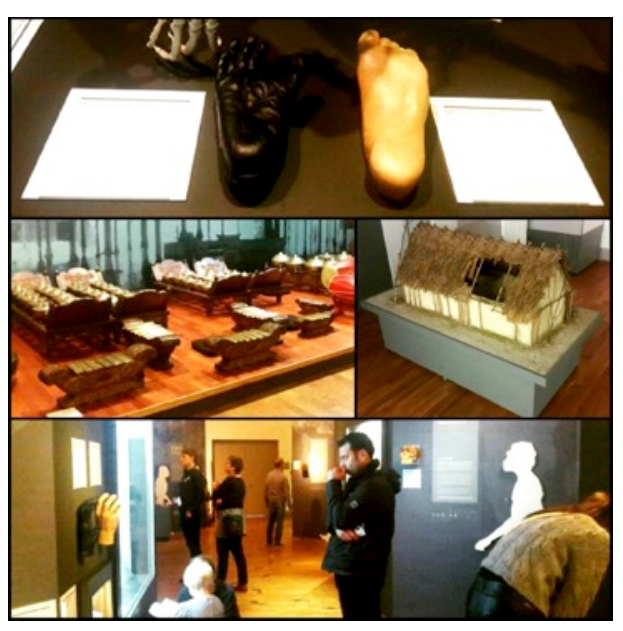

Resim 26. Aşağı Saksonya Eyalet Müzesi (Hannover / Almanya). İç mekândan kesitler. Kaynak: Burak BOYRAZ Arşivi, 2017.

Sergileme yöntemleri adına müze için söylenebilecek ilk şey deneyimlemeyi göz önünde bulunduran ve bunu yaparken de etkileşimsel araçlardan faydalanan bir yaklaşıma sahip olduğudur. Müzede etkileşimselliğe işaret edebileceğimiz ancak dijital altyapıdan destek alma ihtiyacı duymayan araçlar daha çok ziyaretçinin dokunma ve görme duyusuna hitap eden (ve kendi içinde sınırlı mekaniklere sahip olan) araçlardır. Bunlara en başta Doğa Tarihi Koleksiyonu'nun sergi salonlarında rastlanabilir (Bkz. Resim 27 ve 28).

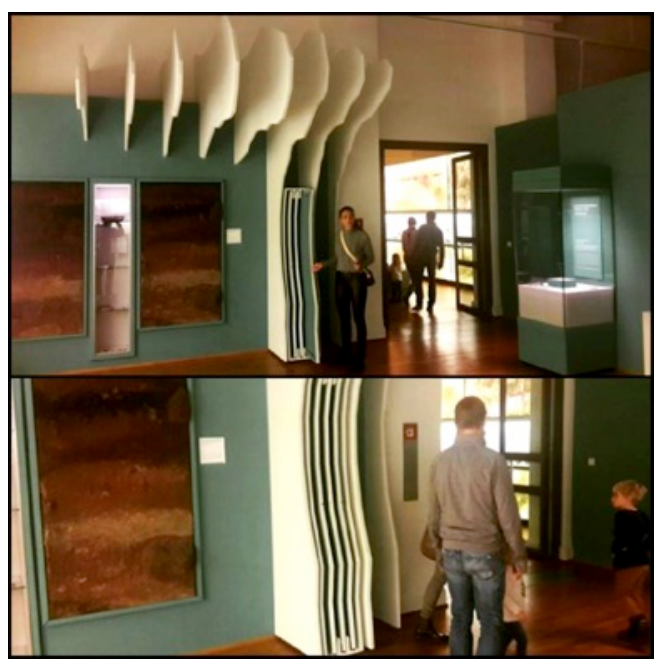

Resim 27. Aşağı Saksonya Eyalet Müzesi (Hannover / Almanya). Doğa Tarihi Koleksiyonu'nun sergi salonunda konumlandırılan etkileşimsel bir bilgi panosu. Ziyaretçiler tarih çağlarının anlatıldığı bu panodaki bilgilere her bir posteri kendilerine doğru çekerek erişmektedir. (Posterler farklı çağları anlatmaktadır). ${ }^{40}$ Kaynak: Burak BOYRAZ Arşivi, 2017.

\footnotetext{
${ }^{38}$ Bünyesinde vivaryumlar da barındırmaktadır. (Vivaryum: Canlıları gözlemlemek için oluşturulan yapay yaşam alanları).

${ }^{39}$ Müze hakkında daha fazla bilgi almak için Bkz.: Boyraz, B. \& Şahin, I. (2018). “Aşağı Saksonya Eyalet Müzesi (Hannover) ve Sanat Koleksiyonu Üzerine Bir Araştırma", V. Uluslararası Yıldız Sosyal Bilimler Kongresi Tam Metinler Kitabı, 13-15 Aralık 2018. İstanbul, ss. 1195-1205.

${ }^{40}$ Öğrenmeyi keyif alarak sağlama amacı güttüğü belli olan bu araçların üretimi için çoğunlukla temel maket malzemeleri kullanılmıştır.
} 


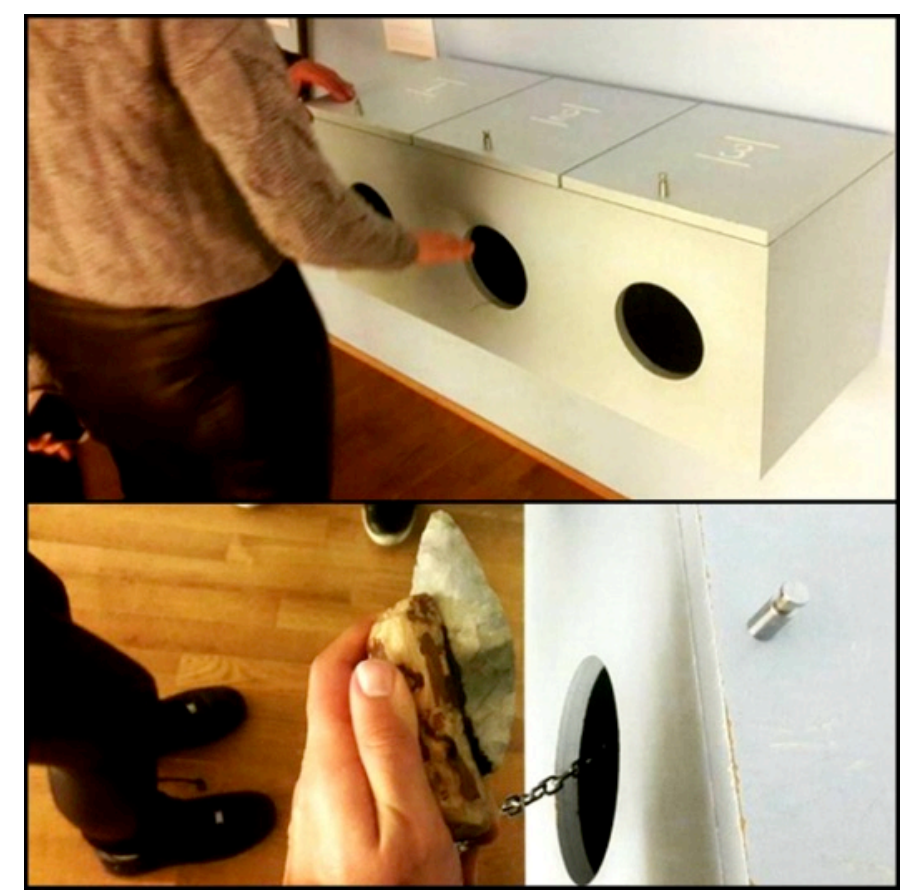

Resim 28. Aşă̆ı Saksonya Eyalet Müzesi (Hannover / Almanya). Tarih öncesi devirlerde kullanılan el aletlerinin replikalarını içeren ve dokunma duyusuna hitap eden bir düzenek. Kaynak: Burak BOYRAZ Arşivi, 2017.

Mevzu bahis koleksiyonun sergilemesine dâhil biçimde kullanılan ve etkileşimsel olup, teknolojiden destek alan araçlara gelirsek, bunlar da özünde yine deneyimleyerek öğrenmeye katkı sağlama amacı güden araçlardır. İlgili araçlar birden fazla duyuya aynı anda hitap edebilmektedir (Bkz. Resim 29).

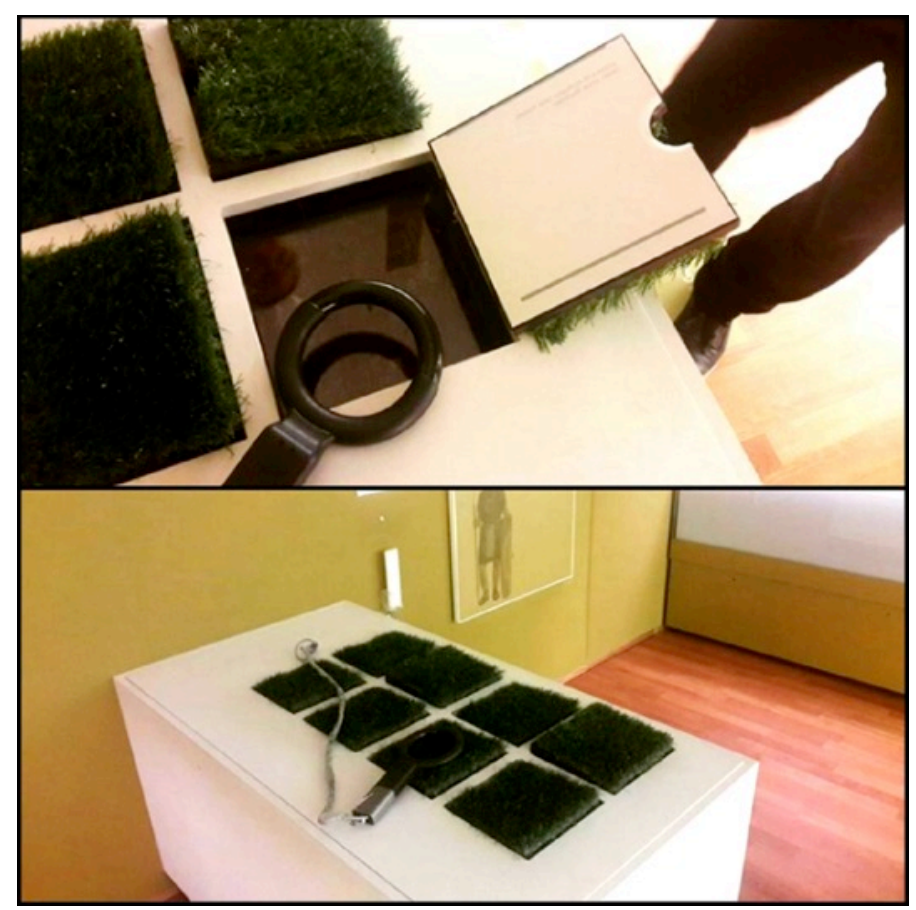

Resim 29. Aşă̆ı Saksonya Eyalet Müzesi (Hannover / Almanya). Doğa Tarihi Koleksiyonu çatısı altında, “Madenler” ve

"Antropoloji" temalarında kullanılan sergileme teknolojileri. Bu araçlar ile ziyaretçilerin madeni kalıntılar ile antropolojik kalıntılar arasındaki farklılıkları, "arama detektöründen" referans alarak tasarlanmış çubukları kullanarak kavraması amaçlanmıştır. Kaynak: Burak BOYRAZ Arşivi, 2017. 
Önceki kısımlarda sıklıkla kiosklardan bahsetmiş̧tik. Aşă̆ı Saksonya Eyalet Müzesi, sergi salonlarında bu türden sergileme teknolojilerine yer vermiştir. Gerek tabletler gerekse kiosklar ziyaretçilere bilgiye pratik ara yüzler üzerinden; infografikler ve kısa videolar ile erişme imkânı tanımaktadır (Bkz. Resim 30 ve 31).

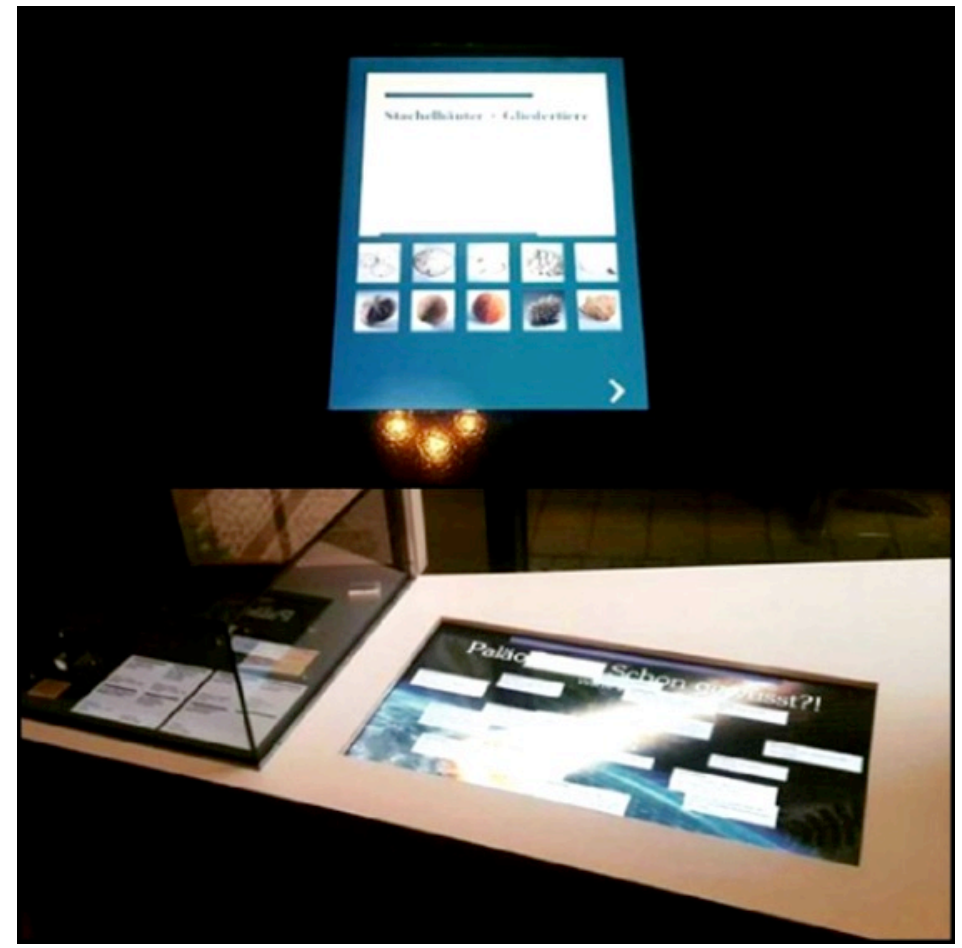

Resim 30. Aşă̆g Saksonya Eyalet Müzesi (Hannover / Almanya). Doğa Tarihi Koleksiyonu'nun sergi salonlarında kullanılan tablet ve kiosk. Kaynak: Burak BOYRAZ Arşivi, 2017.

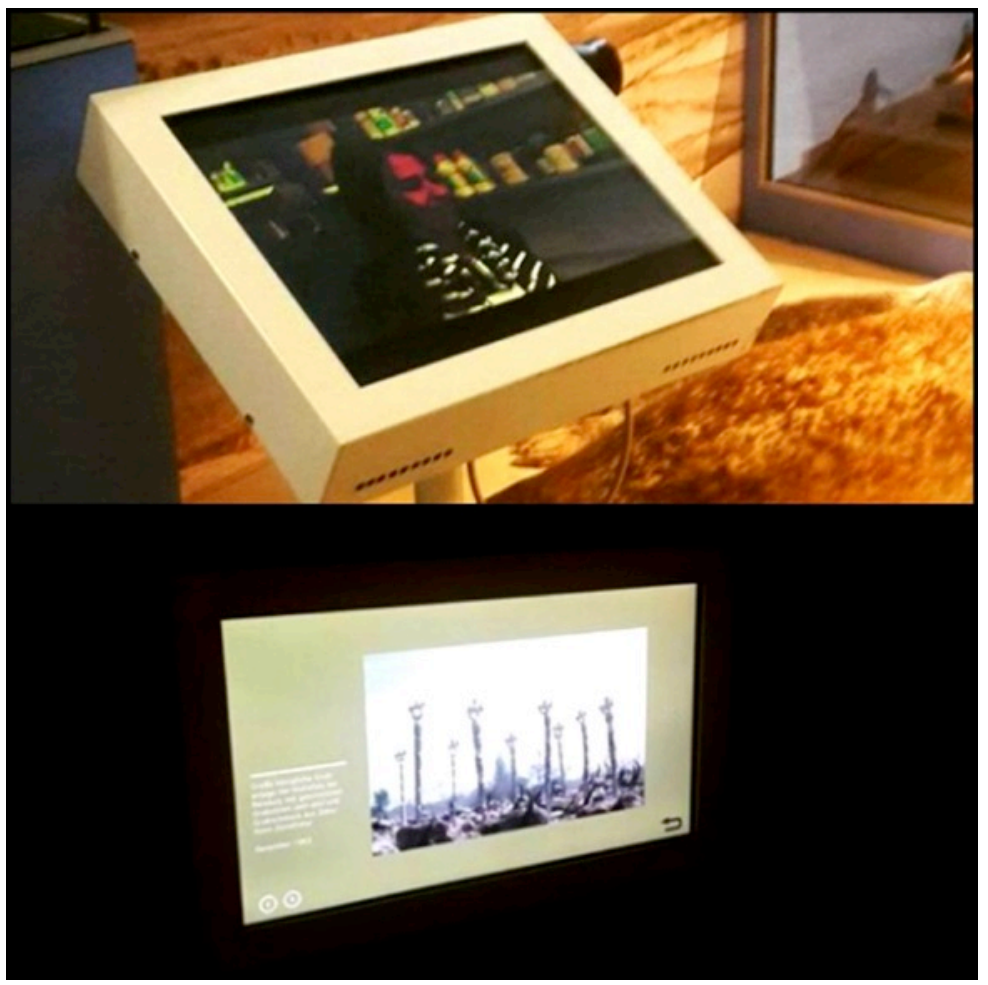

Resim 31. Aşă̆ı Saksonya Eyalet Müzesi (Hannover / Almanya). Doğa Tarihi Koleksiyonu'nun sergi salonlarında kullanılan kiosklar. Kaynak: Burak BOYRAZ Arşivi, 2017. 
Müzede ziyaretçilerin yalnızca işitme duyusuna odaklanan teknolojiler de bulunmaktadır. Bu teknolojiler ile hayvanların çıkardıkları sesleri duyma imkânı yakalanabildiği gibi müze tarihi ve koleksiyonlarına yönelik konu anlatımları da dinlenebilmektedir (Bkz. Resim 32).

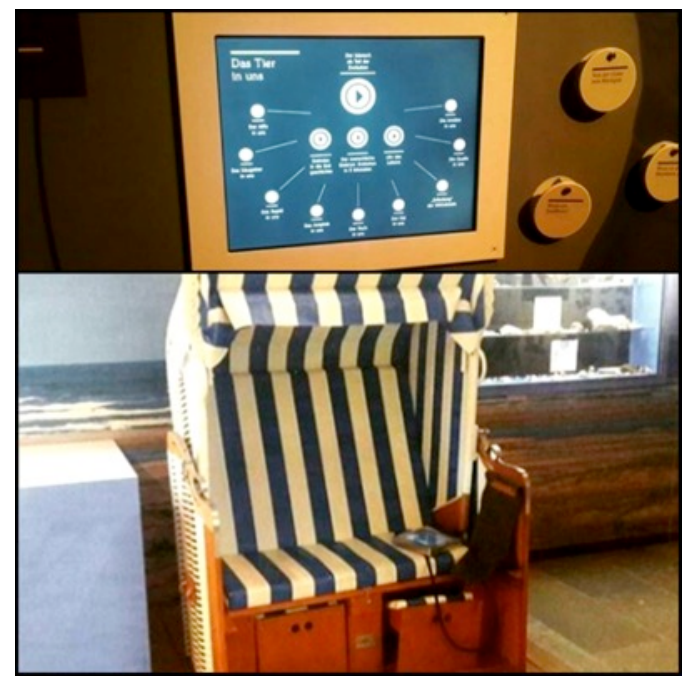

Resim 32. Aşă̆ı Saksonya Eyalet Müzesi (Hannover / Almanya). Doğa Tarihi Koleksiyonu'nun sergi salonlarında kullanılan ve işitme duyusuna odaklanan teknolojiler. Kaynak: Burak BOYRAZ Arşivi, 2017.

Aşağı Saksonya Eyalet Müzesi'nde yakın zamanlı kuşakların oyun alışkanlıkları da göz ardı edilmemiştir. Müzede sergilemenin bir parçası olarak ziyaretçilerin; akıl yürütme, pratik düşünme ve hızlı karar verme gibi özelliklerini test edebileceği dijital oyun mekanizmaları mevcuttur (Bkz. Resim 33). ${ }^{41}$

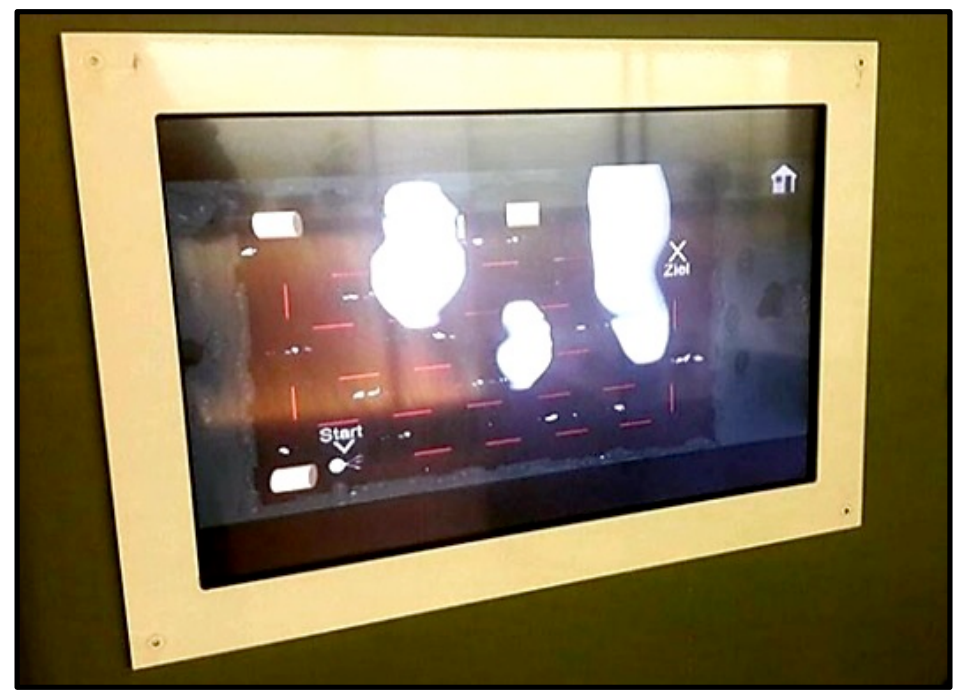

Resim 33. Aşă̆ı Saksonya Eyalet Müzesi (Hannover / Almanya). Doğa Tarihi Koleksiyonu'nun sergi salonlarında kullanılan ve ziyaretçilerin oyun oynamasına imkân veren teknoloji. Özünde ziyaretçilerin motor becerilerinin atalarına göre ne denli geliştiğini vurgulamak için kullanılmıştır. Kaynak: Burak BOYRAZ Arşivi, 2017.

\footnotetext{
${ }^{41}$ Müzelerde oyun konusunu oyun tabanlı öğrenme-öğretme metotları çerçevesinde değerlendirmek gerekir. Eğitim Bilimleri araştırmalarında sıklıkla gündeme gelen bu konu üzerine çalışmalarda bulunan S. Koç Akran ve İ. Kocaman'ın şu şekilde bir ifadesi mevcuttur; "Kısacası oyun tabanlı öğrenme-öğretme modeli çocukların gerçek dünya olayları üzerinde düşünmesini sağladığı için "çocuklarda düşünmenin yapılandırllmasında" önemli bir süreç olarak görülmektedir. Daha sonra bu süreçler eleştirel düşünme, yaratıcı düşünme, problem çözme vb. gibi becerilerin oluşmasını sağlar." (Koç Akran \& Kocaman, 525). Mevzu bahis becerilerin oluşup gelişmesi müzelerin benimsediği hedefler ile uyuşmaktadır.
} 


\section{SONUÇ}

Giriş başlığının ardından sergileme işlevinin 1980 sonrasındaki dönüşümünü bazı anahtar kelimeler üzerinden açıklamaya çalışmıştık. Sonrasında yakın zamanlı saha araştırmalarında topladığımız verilere ve bu verilere dair fotoğraflara yer vermiştik. Bu noktada söylenebilecek en net şey; müzelerin 1980'leri izleyen süreçte sergilerinin niteliklerini arttırmak adına seri biçimde teknolojik araç edinmeye başladığıdır. Toplanan veriler üzerinden bu araçlara dair çıkarımlarda bulunmak mümkündür. İlk olarak Avrupa müzelerinin dijital bağımlılığa hitap edebilecek cihazları kullanmadaki girişimlerine yönelik tespitlere yer verilebilir:

a) İkinci kısımda sunduğumuz görsellerden anlaşılabileceği gibi sergileme konusunda artık sadece; sesli rehberler ve eski tip monitörler kullanılmamaktadır. Hedef kitlelerin ihtiyaçları ve alışkanlıklarının "güncellenmesi" nedeniyle; tabletler, kiosklar, yüksek çözünürlüklü dijital ekranlar, holografi ekipmanları ve oyun konsolları gibi pek çok araç iyiden iyiye demirbaşlar listesine işlenmiştir. Bunlara literatürde bahsi geçen ve sahada da tatbik edilen; sanal gerçeklik gözlüklerini, simülatörleri ve haptik cihazları da eklemek gerekir. Hatta 2010 sonrasında sanal müze uygulamaları yaygınlaşmış42, artırılmış gerçeklikten ${ }^{43}$ söz etmek de olağan hale gelmiştir.

b) Saydığımız teknolojiler Avrupa'daki müzelerin koleksiyon sergilemelerine direk ya da dolaylı yollardan destek vermektedir.

c) Farklı özelliklerdeki teknolojiler aynı ortamda birbirleri ile eşgüdümlü biçimde kullanılabilmektedir. (Bkz. kiosklar ve projeksiyonlar).

d) Söz konusu teknolojileri belirli bir müze türüne atfetmek doğru değildir. İlgili teknolojiler ayrı türlerdeki pek çok müzede yer almıştır. Misyonlarını küratörlerin onları kullanım amaçları veya hedef kitle gruplarının özellikleri belirlemiştir.

e) " $Y$ " ve "Z" kuşaklarının niteliklerini birinci bölümde referanslar eşliğinde belirtmiştik. Avrupa müzeleri teknoloji tüketimi alışkanlığ1 yüksek olan bu kuşakların (bilgiye dijital ortamlar üzerinden erişme ve öğrenirken keyif alma gibi) alışkanlıklarına hitap edecek donanımlara sahiptir.

f) Ziyaretçilerin şahsi tabletleri ve akıllı telefonları artık sergilemenin bir parçası haline gelmiştir. ${ }^{44}$

Sergileme için kullanılan güncel teknolojilerin yeni hizmet ve olanakları da irdelenmiştir.

a) Sergileme için kullanılan teknolojilerin işlevsellikleri özellikle deneyimlemeye katkı sağlayacak biçimde artmıştır.

b) Günümüz sergileme teknolojileri birden fazla duyuyu harekete geçirecek nitelikler de barındırmaktadır.

\footnotetext{
${ }^{42}$ E. Aladă̆, D. Akkaya ve G. Şengöz 2014 yılında yayımlanan Sosyal Bilgiler Dersinde Sanal Müze Kullanımının Öğretmen Görüşlerine Göre Değerlendirilmesi adlı makalelerinde şu şekilde bir bilgiye vermiştir; "Araştırma sonucunda öğretmenlerin sanal müzeleri önemli bir ders materyali olarak gördükleri sonucuna ulaşılmıştır. Bunun nedeni ise öğrencilerin gezme imkânı olmayan müzeleri görme imkânı sunmaları olarak belirtmişlerdir." (Aladağ, Akkaya \& Şengöz, 2014: 213). Aynı makalede Türkiye'yi ilgilendiren bir bilgi olarak; “Öğretmenlerin en çok kullandıkları sanal müzeler şunlardır: Topkapı Sarayı, Anıtkabir, Anadolu Medeniyetleri Müzesi, Ayasofya'dır. Bu müzelerin daha sık kullanılmasının nedeni sosyal bilgiler dersi programına uygun eserler bulunması ve müzelerin tasarım özellikleri olabilir." (Aladağ, Akkaya \& Şengöz, 2014: 213).

43 İç kısımlarda değinmediğimiz ancak 2010 sonrasında popülerleşen artırılmış gerçeklik için bir parantez açmak gerekir. C. Coşkun'un artırılmış gerçeklik ve müzeye dair perspektifi şu şekildedir; "Sanatçılar, küratörler ve müzeler artırılmış gerçeklik teknolojisini kullanarak kendi sanat anlayışları içerisinde farklı ifade biçimlerini ortaya koyabilmektedirler. ... Müzeler ise kendilerine olan ilgiyi artırmak koleksiyonlarında bulunan fakat başka sergileme alanlarında bulunan eserleri müze içerisinde tekrar canlandırmak için kullanabilmektedirler" (Çoşkun, 2017: 72).

${ }^{44}$ Müzelerde sunulan kare kodlar ya da web adresleri üzerinden ilgili uygulamalar (aplikasyonlar) "indirilebilmekte", böylelikle bilgi edinmek için başka bir donanıma gerek duyulmamaktadır. Bu yöntem en başta $Z$ kuşağı bireylerinin ilgisini çekmektedir.
} 
c) Kioskların, yüksek çözünürlüklü dijital ekranların ve sesli rehberlerin görüntü ve ses kalitesi yükselmiştir.

d) Tuşların ve düğmelerin yerini artık dokunmatik ekranlar almıştır.

e) Sergileme teknolojilerinin tasarımları literatürde yer bulan eski örneklerine göre çok daha minimal özellikler taşımaya başlamış, hedef kitle gruplarının alışkanlıkları ve fiziksel durumları üzerinden yapılan çalışmalar ile ergonomi ön plana çıkmıştır.

f) Etkileşimsellik konusunda sergileme teknolojilerinin, teknolojiden destek almayan diğer araçları bütünüyle geri plana attı̆̆ı söylenemez. Avrupa müzelerinde hala dijital alt yapılara sahip olmayan etkileşimsel araçlar kullanılmaktadır.

g) Aynı zamanda iletişim araçları olma özelliğindeki sergileme teknolojileri (tablet ve yüksek çözünürlüklü dijital ekranlar gibi) kablosuz ă̆ kullanımına uygun meziyetlere sahiptir. Bu durum yazılımlarının güncellenmesine ve içeriklerinin yenilenmesine hız kazandırırken, kullanıcılara tanınacak hareket imkânlarının tek bir merkezden (müze tarafından) kontrol edilmesini de kolaylaştırmıştır.

h) Kamera özelliğine sahip olan tablet ve kiosk gibi sergileme araçlarının bazılarında görsel içerikli anlık paylaşımlarda bulunmaya olanak tanımak adına sosyal medya uygulamaları (aplikasyonları) da yer almaktadır.

Edinilen bulgular üzerinden yenilikçi sergileme yöntemlerinde ülkemiz (Türkiye) müzelerinin referans alabileceği yakın dönemli sergiler (veya bu sergileri organize eden müzeler) de saptanmıştır.

Öncesinde belirtilmelidir ki; teknoloji, sergileme konusunda hâlihazırda Türkiye'deki pek çok müzeye entegre durumdadır. Saha araştırmalarında ziyaret ettiğimiz Avrupa müzeleri ile benzer koleksiyonlara sahip olan; Yalova Kent Müzesi (Yalova), Trabzon Şehir Müzesi (Trabzon) ve Adalar Müzesi (İstanbul) gibi kurumlar Türkiye' de güncel sergileme teknolojilerinin kullanımı için örnek gösterilebilecek müzelerdir (Bkz. Resim 34).

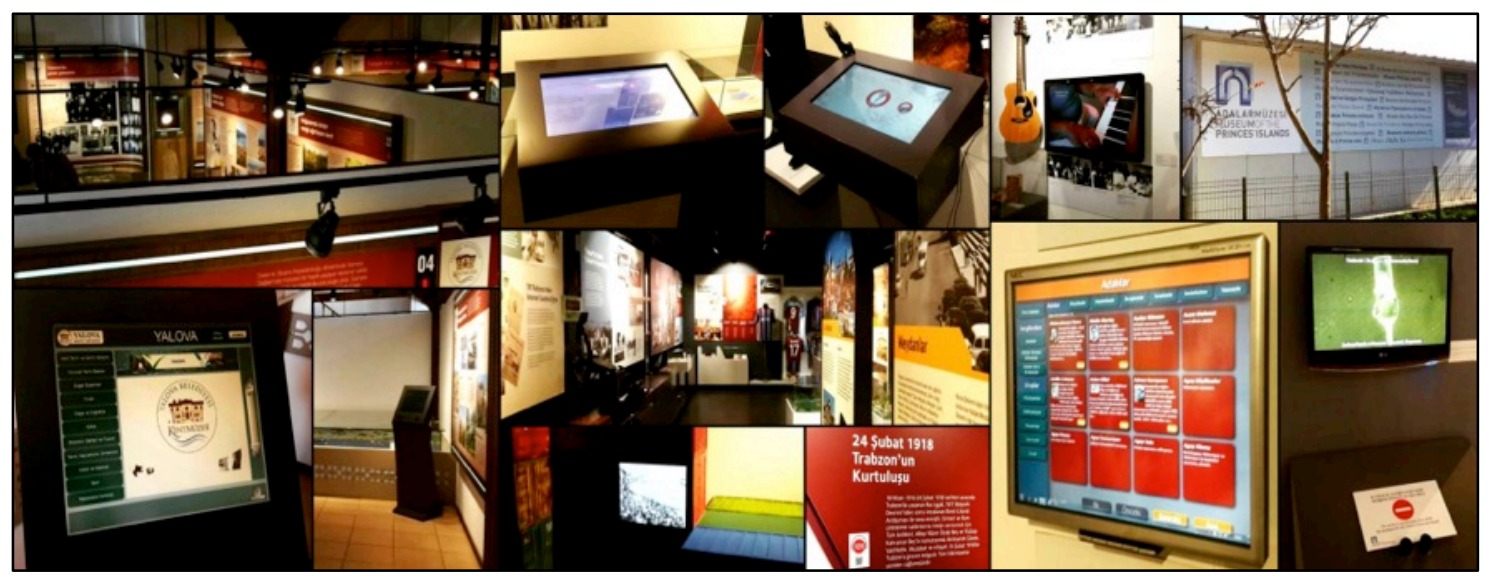

Resim 34. Solda Sağa Yalova Kent Müzesi (Yalova), Trabzon Şehir Müzesi (Trabzon) ve Adalar Müzesi'nde (İstanbul) kullanılan teknolojik ekipmanlardan kesitler. Kaynak: Burak BOYRAZ Arşivi, 2017-2018.

İlgili kurumlardaki teknolojiler ihtiyaç halinde edinileceğini düşündüğümüz holografi teknolojisi dışında Avrupa'dakiler ile benzer özellikler barındırmaktadır. Teknolojiden faydalanmak isteyen müzelerimiz yurt içinde bu kurumlarda ya da müzecilik konusunda aktüel paylaşımlara olanak sunan; Heritage İstanbul 2019 Restorasyon, Arkeoloji ve Müzecilik Teknolojileri Fuarı \& Konferansı gibi etkinliklerde incelemelerde bulunabilir (Bkz. Resim 35).45

45 Türkiye için müzeler ve kültür kurumlarındaki sergilerden söz ederken, dikkat çekici projeleri ile öne çıkan bir isimden de bahsetmek gerekir. Endüstriyel tasarımcı / müze bilimci Burçak Madran (1970) yurt içindeki pek çok müze projesine danışmanlık yapmakta ve sergileme konusunda öncü adımlar atmaktadır. 


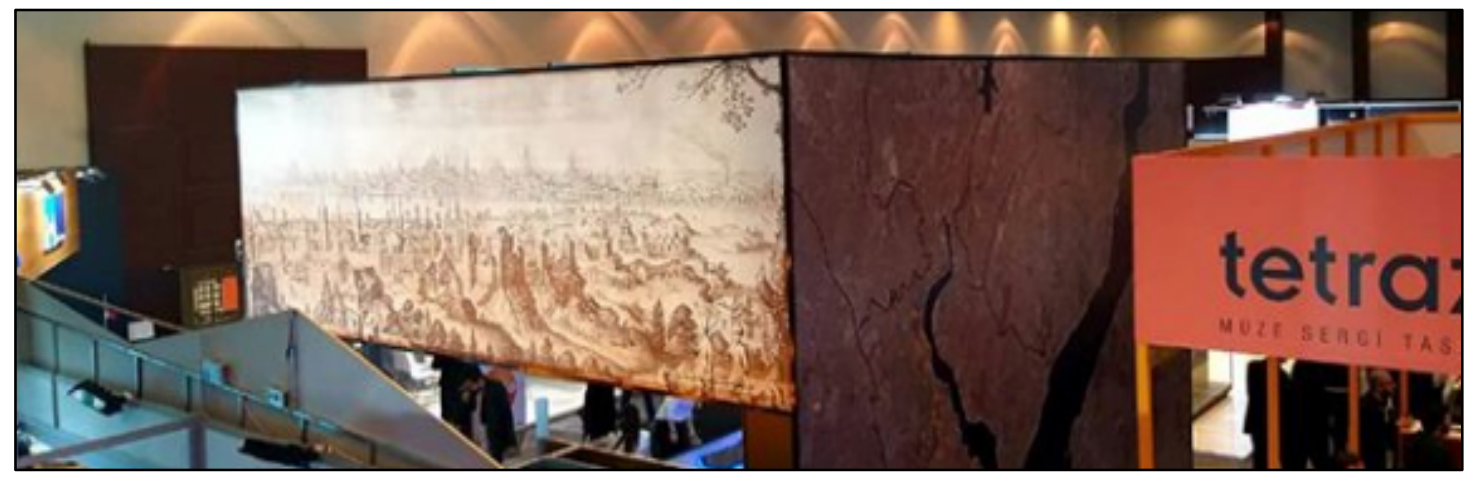

Resim 35. 11 - 13 Nisan 2019 tarihli Heritage İstanbul 2019 Restorasyon, Arkeoloji ve Müzecilik Teknolojileri Fuarı \& Konferansi'ndan bir kesit. Harbiye Hilton İstanbul Convention ile Exhibition Center. İstanbul. Kaynak: Burak BOYRAZ Arşivi, 2019.

Yurt dışında araştırma yapmayı hedefleyen müzelerimiz ise ikinci kısımda yer verdiğimiz tüm müzeleri ziyaret edebilir. Avrupa' da yer alan bu müzelerde sergileme teknolojisi olarak öne çıkan araçlar aşağıdaki tabloda belirtilmiştir (Bkz. Tablo 2).

Tablo 2. Araştırma İçin Ziyaret Edilen Ülkelerde Öne Çıkan Sergileme Teknolojileri.

\begin{tabular}{|c|l|l|l|l|}
\hline Sıra & $\begin{array}{l}\text { Ziyaret } \\
\text { Edilen Ülke }\end{array}$ & $\begin{array}{l}\text { Ziyaret Edilen } \\
\text { Şehir }\end{array}$ & Ziyaret Edilen Müze & Öne Çıkan Sergileme Teknolojileri \\
\hline $\mathbf{1}$ & Fransa & Strazburg & Strazburg Tarih Müzesi & $\begin{array}{l}\text { Sesli Rehberler, Kiosklar, Yüksek } \\
\text { Çözünürlüklü Dijital Ekranlar, } \\
\text { Projeksiyonlar, Holografi } \\
\text { Teknolojisi. }\end{array}$ \\
\hline $\mathbf{2}$ & Sırbistan & Belgrad & $\begin{array}{l}\text { Strbistan Tarih Müzesi \& } \\
\text { Nikola Tesla Müzesi }\end{array}$ & $\begin{array}{l}\text { Sesli Rehberler, Kiosklar, Yüksek } \\
\text { Çözünürlüklü Dijital Ekranlar, } \\
\text { Projeksiyonlar, Holografi } \\
\text { Teknolojisi. }\end{array}$ \\
\hline $\mathbf{3}$ & Yunanistan & Atina & $\begin{array}{l}\text { Akropolis Müzesi ve Kiklad } \\
\text { Sanat Müzesi }\end{array}$ & $\begin{array}{l}\text { Sesli Rehberler, Kiosklar, Yüksek } \\
\text { Çözünürlüklü Dijital Ekranlar. }\end{array}$ \\
\hline $\mathbf{5}$ & Almanya & Hannover & $\begin{array}{l}\text { Zagreb Çağdaş Sanatlar } \\
\text { Müzesi \& Zagreb Tarih Müzesi }\end{array}$ & $\begin{array}{l}\text { Sesli Rehberler, Kiosklar, Yüksek } \\
\text { Çözünürlüklü Dijital Ekranlar. }\end{array}$ \\
\hline
\end{tabular}

Son olarak temas edilecek konu Avrupa Birliği projeleri veya kalkınma fonları çerçevesinde Batı müzeler ile iş birliği yapma fırsatıdır. Bu noktada en başta kent müzelerimizin Tablo 2'de yer verdiğimiz müzeler ile ortaklıklar kurabileceğini söylemek gerekir. Söz konusu ortaklıklar ile sergilemenin yanı sıra; araştırma, bakım-koruma, belgeleme ve eğitim etkinlikleri gibi müzeciliğin diğer işlevlerinde de teknik bilgi kazanılması son derece muhtemeldir.

\section{Notlar:}

1- Metni tamamlarken teknoloji ile ilgili bir sorunsala temas etmek, sonraki yıllarda sergileme teknolojileri üzerinde çalışmayı hedefleyen uzmanlar için faydalı olacaktır. Bu sorunsal teknolojideki hızlı değişimin sergileme teknolojilerinin kullanım ömürlerine olan etkisi, diğer bir deyişle müzenin edindiği donanımın sürdürülebilirliğidir. Yalın bir ifadeyle: “Bugün müzeler sergileme amacıyla kullandıkları teknolojik cihazları bozulmalar, kullanımda yaşanan sorunlar, diğer teknolojilerle uyumsuzluk ve anlatımda yeterli olamama gibi sebeplerden dolayı sürekli olarak yenilemektedir. Yeni teknolojilerin bir öncekilerden üstün olmasının dışında bu değişime sebep olan bir başka etken ise mevcut teknolojinin 
sergileme amacına hizmet edememesidir. ${ }^{46}$ Müzelerde bulunan sergileme teknolojileri bazen müzede sergilenen nesnelerin vermek istediği mesajı aktarmada etkisiz ya da yetersiz kalabilmektedir" (Boyraz, 2011: 51).47 Bu gibi durumlar ile karşılaşmamak için sergileme teknolojilerinden faydalanacak olan müzeler uzun vadeli düşünmeli, planlı hareket etmeli ve ilgili teknolojilerin bakım ve onarım ihtiyaçları göz ardı edilmemelidir. ${ }^{48}$

2- Araştırmanın Fransa ayağına vesile olan projenin künyesi için Bkz.: (2012). Avrupa Birliği / Türkiye Kültürlerarası Diyalog - Müzeler Hibe Programı. “University Museums In EU Countries \& Turkey” Projesi. Yürütücüler: A. Sultan Karaoğlu \& Özcan Gündoğdu. Proje No: TR0803.02-02/27. Proje Bütçesi: 118.403 Euro. Proje İştirakçileri: Kocaeli Üniversitesi, Prof. Dr. Baki Komsuoğlu Müzesi. İzmit / Türkiye, Strasbourg University, Jarden des Sciences. Strasbourg / France.

\section{KAYNAKÇA}

Acar, A. (2017). Müze ve Sergilemelerde Etkileşimli Tasarım Çözümleriyle Bilgiyi Görselleştirmek, Hacettepe Üniversitesi Güzel Sanatlar Fakültesi Sanat Yazıları, 36: 139-155.

Aladağ, E., Akkaya, D. ve Şensöz, G. (2014). Sosyal Bilgiler Dersinde Sanal Müze Kullanımının Öğretmen Görüşlerine Göre Değerlendirilmesi. Trakya Üniversitesi Sosyal Bilimler Dergisi, 16 (2): 199-217.

Alpay, H. R. (1989). Teknolojik Bağımlılık ve Yaratıcı Mühendislik Eğitiminin Gerekliliği. Sanayi Kongresi Bildirileri. TMMOB Sanayi Kongresi. Ankara: TMMOB. 9-12.

Atagök, T. (1999). Yaşayan Müze ve Eğitim, Sanat Dünyamız, 71: 223-227.

Ayan Ergen, B. (2013). Sanat Yapıtı Sergileme ve Sunum Çeşitlerine Örnekler Eşliğinde Bir Bakış, Akdeniz Sanat Dergisi, 6(11): 130-143.

Aykut, Z. (2017). Müze Sergilemelerinde İzleyici-Sergi Etkileşimi Bağlamında Mekân Tasarımı. Uluslararası Disiplinlerarası ve Kültürlerarası Sanat, 2 (2): 219-242.

Boratav, O. ve Gürdal, N. (2016). 1980 Sonrası Sergileme. Art-Sanat Dergisi, (6): 169-183.

Boyraz, B. ve Şahin, I. (2018). Aşağı Saksonya Eyalet Müzesi (Hannover) ve Sanat Koleksiyonu Üzerine Bir Araştırma, V. Uluslararası Yıldız Sosyal Bilimler Kongresi Tam Metinler Kitabı, 13-15 Aralık 2018. İstanbul, ss. 1195-1205.

Boyraz, B. (2011). Müzelerde Sergileme Yöntemleri Bağlamında Teknoloji Kullanımı, Yüksek Lisans Tezi, YTÜ Sosyal Bilimler Enstitüsü, Müzecilik Yüksek Lisans Programı. İstanbul.

Coşkun, C. (2017). Bir Sergileme Yöntemi Olarak Artırılmış Gerçeklik. Sanat ve Tasarım Dergisi, (20): 61-75.

Çolak, B. (2011). Tarihsel Süreç İçerisinde Müzelerle Birlikte Değişen Sergileme Mekânları; New York Modern Sanat Müzesi (MoMA) ve Frankfurt Modern Sanat Müzesi (MMK) Örneği. Erciyes Üniversitesi Sosyal Bilimler Enstitüsü Dergisi, 1 (30): 37-45.

\footnotetext{
${ }^{46} \mathrm{Z}$. Aykut'un belirttiği gibi; "Sergilemelerin ziyaretçiler tarafindan kolay anlaşılabilir, ilgi çekici, merak uyandırıcı olabilmesi ve hikâyenin anlatılabilmesi için anlatının içeriğine göre mekân tasarımına ihtiyaç vardır. Mekân oluşturan sergi tasarım ögelerinin ise bir bütün olarak hikâyenin anlatılmasına hizmet etmesi gerekir" (Aykut, 2017: 2019).

47 "Örneğin çă̆daş, sanat müzeleri, düzenledikleri sergilerde sıra dışı sanat eserlerine yer vermektedir. Serginin vermek istediği mesaj ayrı bir konudur. Fakat bu sergiyi anlatımsal olarak destekleyecek teknolojilerin tercihinde kimi zaman mevcut teknolojinin sergi nesnesinin önüne geçmesi ya da sergi nesnesini desteklemede yetersiz kalması müzeler için kullanılabilirliği etkileyen önemli bir sorunlardır. Dolayısıyla kullanılabilirlik mevcut teknolojilerin sergilenecek eserlerle olan uyumu ile ilişkilidir" (Boyraz, 2011: 51). ${ }^{48}$ Ayrıca belirtmek gerekir ki, günümüz müzeleri güncel teknolojileri yakından incelemek, bünyelerine uygun sergileme teknolojilerini saptamak ve bunların kullanım ömürlerini değerlendirmek için kendi uzmanlarını ve küratörlerini; ilgili eğitim programlarına, seminerlere, sempozyumlara, konferanslara, çalıştaylara ve müzecilik yüksek lisans programlarına dâhil olmaya teşvik etmeli, gerekli kolaylığı sağlamalıdır.
} 
Demir, Ç. (2008). Günümüz Sergileme Tasarımı, Türleri ve Londra'dan Sergileme Tasarımı Örnekleri. Gazi Sanat ve Tasarm Dergisi, (2): 51-65.

Erten, P. (2019). Z Kuşağının Dijital Teknolojiye Yönelik Tutumları. Gümüşhane Üniversitesi Sosyal Bilimler Enstitüsü Elektronik Dergisi, 10 (1), 190-202.

Güçlü, N. ve Sotirofski, K. (2006). Bilgi Yönetimi, Türk Eğitim Bilimleri Dergisi, 4(4): 351-372.

Kandemir, Ö. ve Uçar, Ö. (2015). Değişen Müze Kavramı ve Çağdaş Müze Mekânlarının Oluşturulmasına Yönelik Tasarım Girdileri. Anadolu Üniversitesi Sanat ve Tasarım Dergisi, 5(2), 1747.

Karadeniz, C. (2017). Müze ve Toplum: Müzeyle Topluma Ulaşmak, İnsan ve Toplum Bilimleri Araştırmaları Dergisi, 6(8): 19-37.

Keş, Y. ve Başer Akyürek, A. (2018). Teknoloji İle Büyüyen Yeni Nesil İçin İnteraktif Müzeler. Medeniyet Sanat Dergisi, 4 (2): 95-110.

Koç Akran, S. ve Kocaman, İ. (2018). Oyun Tabanlı Öğrenme-Öğretme Yaklaşımının Okul Öncesi Öğrencilerinin Öğrenme Tercihlerine Etkisi. Gazi Üniversitesi Gazi Eğitim Fakültesi Dergisi, 38 (2), 513-533.

Kurak Açıcı, F., ve Konukoğlu, Z. (2018). Kültürel Mirasın İzlerini Kent Müzelerinde Sürmek: Trabzon Müzeleri. Journal of History Culture and Art Research, 7(3), 668-682.

Kurşuncu, A. (2019). Seramik Sanatında Sergileme Sorunları. Yedi, (21): 43-51.

Küçükerdoğan, R. (2012). Reklam İletişimi Açısından Hedef Kitle Çözümlemesi. İstanbul Üniversitesi İletişim Fakültesi Dergisi, (9): 319-343.

Okan, B. (2015). Günümüz Müzecilik Anlayışı, AÜ Sanat ve Tasarım Dergisi, 9:187-197.

Sakarya, K. (2018). Koleksiyon Figürü Sergileme Ünitelerinde Tasarım Kriterleri. Asia Minor Studies, 6 (AGP Sempozyum Özel Sayısı), 121-137.

Şahan, M. (2005). Müze ve Eğitim. Türk Eğitim Bilimleri Dergisi, 3(4): 487-501.

Şar, E. ve Sağkol, T. (2013). Eğitim Fakültelerinde Müze Eğitimi Dersi Gerekliliği Üzerine. HAYEF Journal of Education, 10 (2): 83-90.

Taş, H. ve Kaçar, S. (2019). X, Y ve Z Kuşağı Çalışanlarının Yönetim Tarzları ve Bir İşletme Örneği. OPUS Uluslararası Toplum Araştırmaları Dergisi, 11(18), 643-675.

TDK, 2019. www.tdk.gov

Tuncer, M. (2016). A ̆ Toplumunun Çocukları: Z Kuşağının Kişilerarası İletişim Becerilerinin Çok Boyutlu Analizi. Atatürk İletişim Dergisi, (10), 33-46.

Yılmaz, B. (2002). Bilgi Toplum İlişkisi ve Türkiye, Hacettepe Ü. Edebiyat Fakültesi Dergisi, 19(2): 101-114.

\section{Görsel Kaynakçası}

Burak Boyraz Arşivi. 